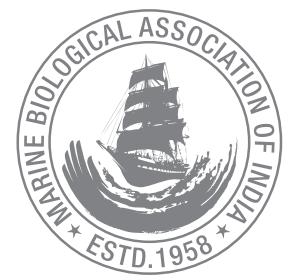

\title{
Six new species of Hyattella (Porifera: Dictyoceratida: Spongiidae) from the Southern Coast of India
}

\author{
M. S. Varsha ${ }^{1,2}$, K. K. Joshi ${ }^{1 *}$ and S. Jasmine ${ }^{3}$ \\ IICAR-Central Marine Fisheries Research Institute, Kochi-682 018, Kerala, India. \\ ${ }^{2}$ Cochin University of Science and Technology, Kochi-682 022, Kerala, India. \\ ${ }^{3}$ Research Centre of ICAR-Central Marine Fisheries Research Institute, Vizhinjam -695 521, Kerala, India. \\ *Correspondence e-mail: joshyguru@gmail.com
}

Received: 07 July 2020 Accepted: 25 July 2020 Published: 30 July 2020

Original Article

\begin{abstract}
The Sponges of the family Spongiidae have seven genera and occur in a wide variety of forms from low encrusting to upright massive forms. Among these the species of the genus Hyattella from India had been described in a very confusing manner. Present work revises the species reported from India. Six new species Hyattella repandus n. sp., Hyattella macrophylla n. sp., Hyattella foliata n. sp., Hyattella vedalainensis n. sp., Hyattella diffusa n. sp. and Hyattella oblongus n. sp. were added to the fauna of India. The Hyattella macrophylla n. sp. has uneven surface with folding, less cored primary fibres and smaller diameter of primary fibres. The Hyattella foliata $n$. sp. is like flower petals shape, thicker diameter of primary as well as secondary fibres. Hyattella vedalainensis $\mathrm{n}$. sp., is characterised by a small arborescent flat sponge body, small oscules, densely cored primary fibers as compared to other four species. H. diffusa $\mathrm{n}$. sp. is an arborescent, small tubular branch and high diameter of the primary fibres. The H. oblongus $n$. sp. is a globate and massive, less diameter of the primary fibres.
\end{abstract}

Keywords: Diversity, marine sponges, Demospongiae, Gulf of Mannar, Hyattella

\section{Introduction}

Family Spongiidae Gray, 1867 consists of six valid genera and 91 nominal species. They are characterised by homogenous skeletal fibres and dense fibre skeleton of primary and secondary fibres (Cook and Bergquist, 2002). The first important work on "horny sponges" was by Lendenfeld in 1889 who published a detailed account of the taxonomy, morphology and physiology of this group. Bergquist (1980) described the Horny sponges- mineral skeleton is replaced by collagenous elements which is mainly spongin fibres, reduced to fibrillar collagen which reinforces the sponge matrics. It is interesting to note that the so-called "horny" sponges have been variously grouped at ordinal level as the Keratosa (Grant, 1861; Burton, 1934; De Laubenfels, 1936; 1948; Vacelet, 1959); Monoceratina, Dendroceratina and Myxospongiae (Minchin, 1900), Euceratosa (Dendy, 1905); Dictyoceratida and Dendroceratida (Bergquist and Hartman, 1969; Lévi 1973) Dictyoceratida, Dendroceratida and Verongida (Bergquist, 1978).

Cook and Bergquist (2001) reported that the Genus Spongia assigned to Dictyoceratida has the greatest number of species than any genus. Six genera: Spongia, Hippospongia, Coscinoderma, Hyattella, Leiosella and Rhopaloeides, occur in a variety of forms from low encrusting to upright massive forms. 
They all have a skeleton of primary, secondary, and distinct fine or pseudo-tertiary fibres. All fibres are unpithed and are homogeneous. Most characteristic of the sponge is the dense secondary fibre reticulum, which dominates the skeleton. The surface of the sponge may be heavily armoured in a dermal crust of sand, foreign spicules and detritus. Unarmoured genera usually have a conulose surface. Choanocyte chambers are diplodal, spherical to oval in shape.

Cook (2007) described that Dictyoceratid Families have fine collagenous filaments-Ircinids, homogenous SkeletonSpongids, eurypylous choanocyte chambers-Thorectids, diplodal choanocyte chamber, pithed and laminated fibres and absence of fine filaments. The generic characters considered for the species differentiation were skeletal architecture, mucus production, whether they are armoured or not armoured, presence of primary, secondary and tertiary fibres, fascicular fiber and foreign coring. Dictyoceratids have an anastomosing fibre skeleton, usually organised into a hierarchy reflecting size and orientation.

Primary fibres are typically oriented at right angles to the surface; distally they usually end at the sponge surface and support the conules in those species that have them (Bergquist, 1980). They may be simple, coalescing to fascicular. May be axially to fully covered with foreign inclusions e.g: sand, spicule. Secondary fibres: typically interconnect primary fibres (Cook and Bergquist, 2002) in the simple form they look like rungs of a ladder. May be axially to fully cored with foreign materials. Tertiary fibres: interconnect secondary ones (Cook and Bergquist, 2001), uncored, usually very fine-fibres of very small diameter in comparison with secondary fibres. They form a fine meshnetwork within the secondary fibre meshes. Pseudo-tertiary fibres: Finer than secondary fibres, not as fine as tertiary fibres (Cook and Bergquist, 2002).

Hyattella is characterised by an unarmoured and conulose surface, lacunose sponge body and commonly cored primary and uncored secondary fibres. They are elastic and compressible. A total of 34 species was described globally, of which 24 are valid. Previous studies indicate that there are around 14 species of Hyattella found globally (Lendenfeld, 1889; De Laubenfels, 1936; 1948; 1954; Thomas, 1973; Van Soest, 1978; Bergquist, 1980; Cook and Bergquist, 2002; Van Soest et al., 2020). Recently, nine species of Hyattella were recorded off the Chinese coast (Sim and Lee, 2014; Sim et al., 2015). Up to now, seven species of the genus Hyattella have been reported from India: Hyattella cribriformis (Hyatt, 1877), Hyattella intestinalis (Lamarck, 1814), Hyattella meander Lendenfeld, 1889, Hyattella pertusa (Esper, 1794), Hyattella sinuosa (Pallas, 1766), Hyattella tubaria Lendenfeld, 1889 and Hyattella globosa Lendenfeld, 1889). There exists a great diversity of Hyattella around the world especially in the tropical seas. Moreover, the reports from India have been scarce and there are nomenclature issues of the species reported from Indian Ocean (Dendy, 1887; 1889; Burton, 1937; Rao, 1941; Thomas, 1973; 1979; 1985; 1986; Prabhakaran et al., 2013; Sivaleela, 2014; Van Soest et al., 2020; Tarachand et al., 2020; Varsha et al., 2020 a; 2020 b; 2020 c). In this context the present exploration and taxonomic work on the bio-inventorying of Sponge of the Genus Hyattella was taken along the Indian coast with special emphasis along the Gulf of Mannar area which is part of the All India Coordinated Project on Taxonomy (AICOPTAX) a new initiative from the Ministry of Environment, Forests and Climate Change, New Delhi to create a database on the inventory of the faunistic diversity of India.

\section{Material and methods}

An extensive survey and sampling at selected stations was conducted from both south west and south east coast of India i.e., Muttom, (10.11.2018), Vedalai, (06.05.2019), Mandapam, (21.07.2019) and Chetlat Island (26.09.2019) (Fig.1). Muttom is one of the historical fishing villages located in the south west coast of India characterized by rocky habitat and calm sea wherein the diversity emanates from the Arabian Sea of Indian Ocean. Along the south east coast, Vedalai is an ancient fishing village situated in the south of Gulf of Mannar that lies in the Bay of Bengal Sea. The two coral Islands on both sides of Vedalai makes its unique habitat with vulnerable and threatened species and forms a part of Marine Protected Area of Gulf of Mannar Marine National Park. Mandapam is a coastal town that lies between Gulf of Mannar and Palk Bay of Bay of Bengal Sea. The samples were collected for the present study from the Palk Bay side of the Bay of Bengal Sea. Chetlat Island is a coral island of the Lakshadweep Archipelago. The reef and lagoon are located to the west of the island that has a lagoon area of $3.79 \mathrm{~km}^{2}$. It lies between $11^{\circ} 41^{\prime}$ and $11^{\circ} 43^{\prime} \mathrm{N}$ latitude and $72^{\circ} 41^{\prime}$ and $72^{\circ} 43^{\prime} \mathrm{E}$ longitude having an area of $1.40 \mathrm{~km}^{2}$.

Sponges were collected by handpicking, snorkeling and SCUBA diving at various localities at a depth of $0-50 \mathrm{~m}$. Specimens of three species from Muttom - (Field collection numbers: MT 32, MT 53, MT 71, MT 50) two species from Vedalai (VD 12, VD 23) two species from Mandapam (MD 02, MD 13) and specimen from Chetlat (CHT 8) were collected and anlaysed during the present study. The collected samples were brought to the laboratory and preserved in dry condition and $70 \%$ of Ethanol. The sectioning of the samples were done using razor blades and thin sections were preserved. Structural characteristics and length measurements of spicules were noted using the Nikon SMZ 1000 Stereozoom microscope and image analyzing 

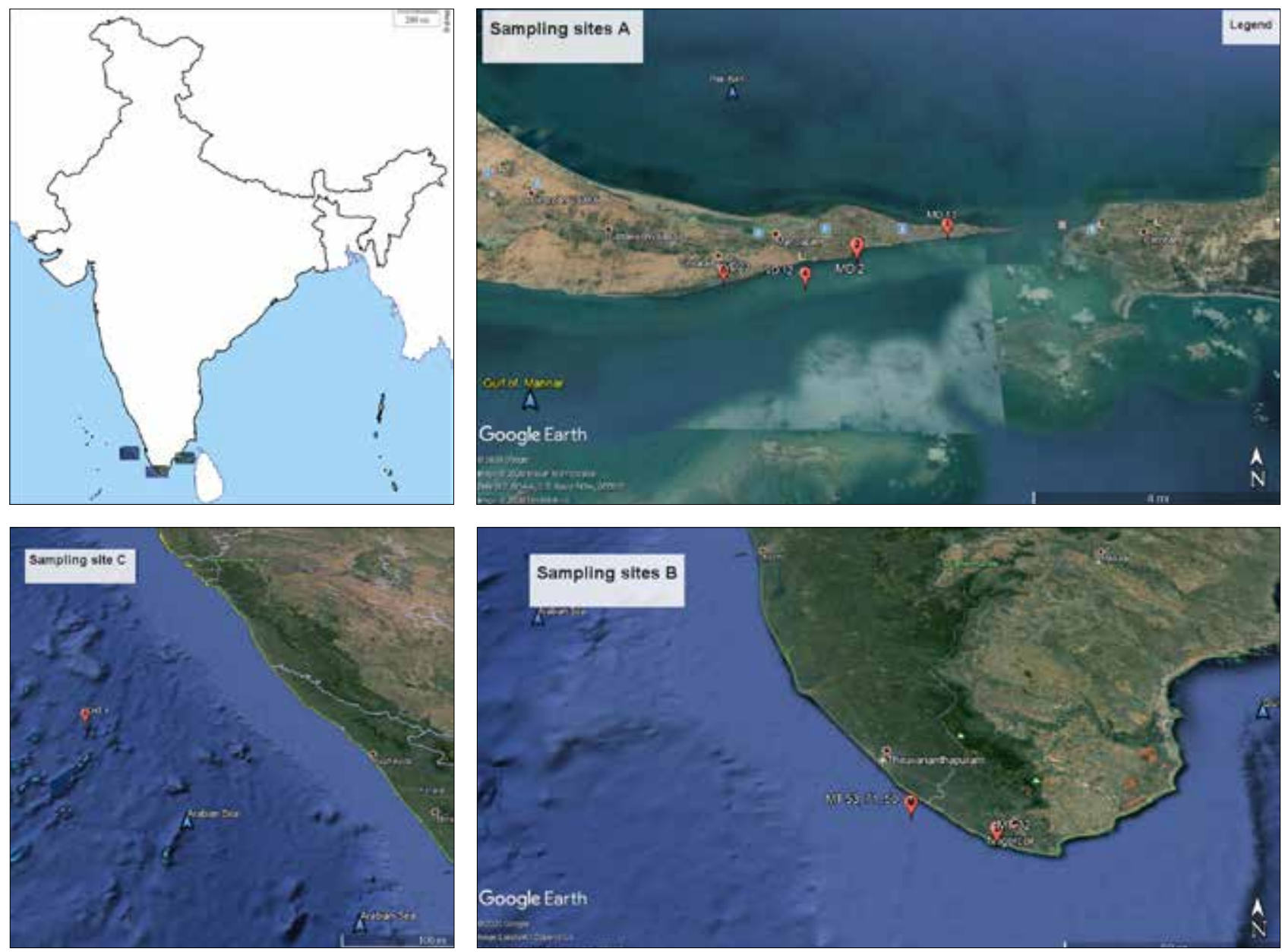

Fig.1. Map showing sampling stations of Hyattella species from Gulf of Mannar and Southern Arabian Sea. Site A: VD 12, VD 23, MD 02, MD 13, Site B: MT 53, MT 71, MT 50, MT 32 and site C: CHT 8 are the places where the sampling was done.

software NIS ELEMENTS Version 4.20 (Nikon). The width of the primary fibres were measured and observed the coring pattern and materials. The width of the secondary and tertiary fibres measured in the same way. The sponges were identified as per the detailed diagnostic characters given in the literature (Lendenfeld, 1889; Bergquist, 1980; Bergquist, 1982; Cook and Bergquist, 2001; Cook and Bergquist, 2002; Cook, 2007; Hooper and Van Soest, 2002).

\section{Results}

Phylum : : Porifera Grant, 1836

Class : Demospongiae Sollas, 1885

Subclass : : Keratosa Grant, 1861

Order : : Dictyoceratida Minchin, 1900

Family : : Spongiidae Gray, 1867

Genus : Hyattella Lendenfeld, 1888

Type species : Hyattella intestinalis (Lamarck, 1814)

\section{Hyattella intestinalis 1 (Lamarck, 1814)}

(Fig. 2-4, 5-7, Table 1)

Synonyms:

Carteriospongia clathrata (Carter, 1881)

Carterispongia clathrata (Carter, 1881)

Hippospongia anomala Poléjaeff, 1884

Hippospongia clathrata (Carter, 1881)

Hippospongia intestinalis (Lamarck, 1814)

Hircinia clathrata Carter, 1881

Hyattella clathrata (Carter, 1881)

Hyattella murrayi Lendenfeld, 1889

Hyattella velata (Hyatt, 1877)

Ircinia clathrata (Carter, 1881)

Spongelia velata Hyatt, 1877

Spongia cariosa Lamarck, 1814

Spongia intestinalis Lamarck, 1814

Spongia tubulosa Lamarck, 1814

Stelospongia kingii Lendenfeld, 1889 


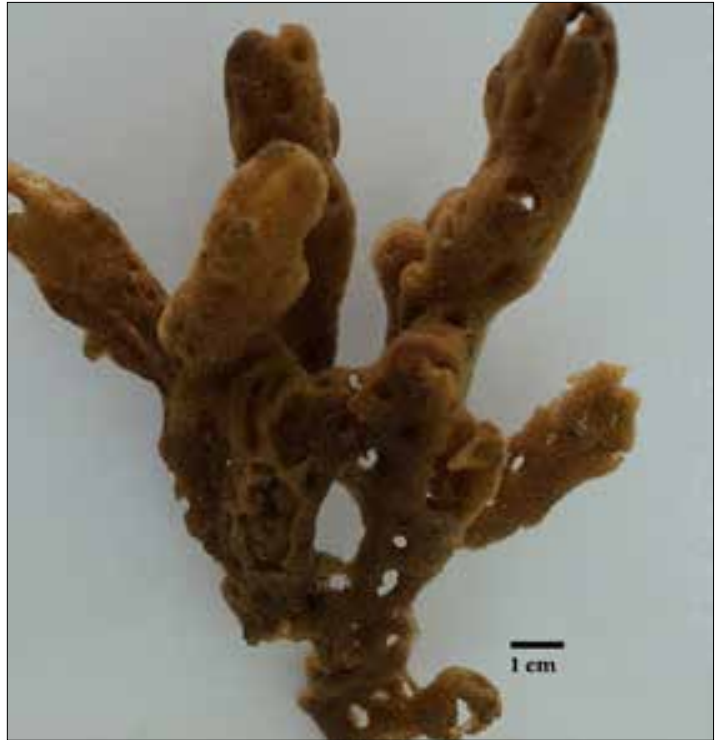

Fig. 2. Hyattella intestinalis 1 (Lamarck, 1814) CMFRI DNR No. BA.1.1.2.9

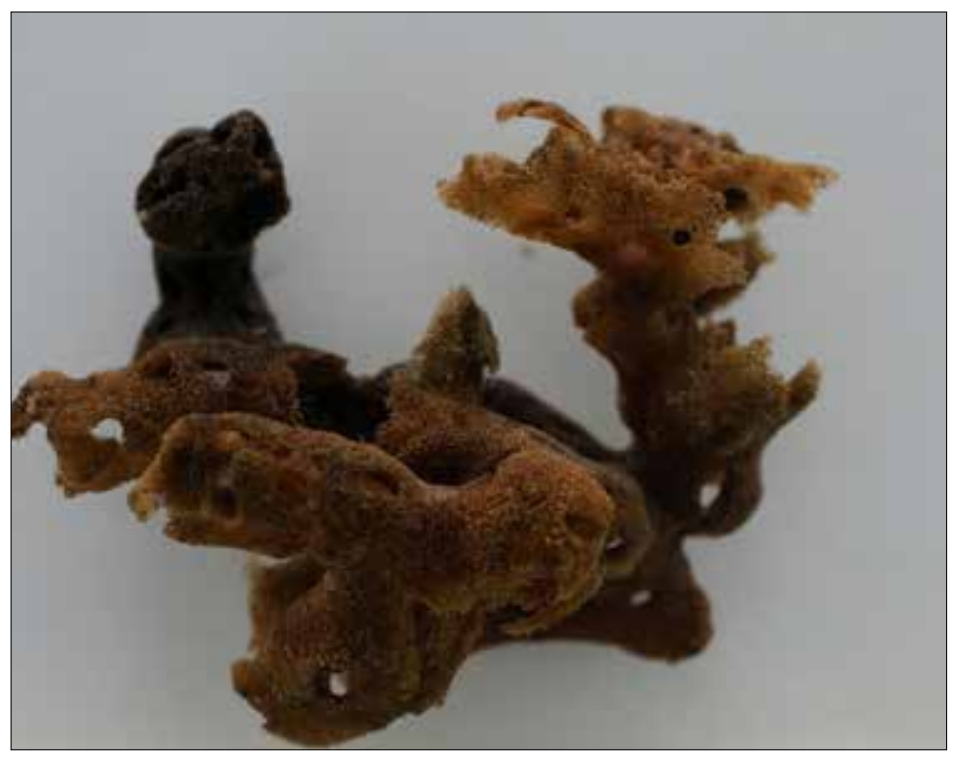

Fig. 3. Hyattella intestinalis 2 (Lamarck, 1814) CMFRI DNR No. BA.1.1.2.9.2

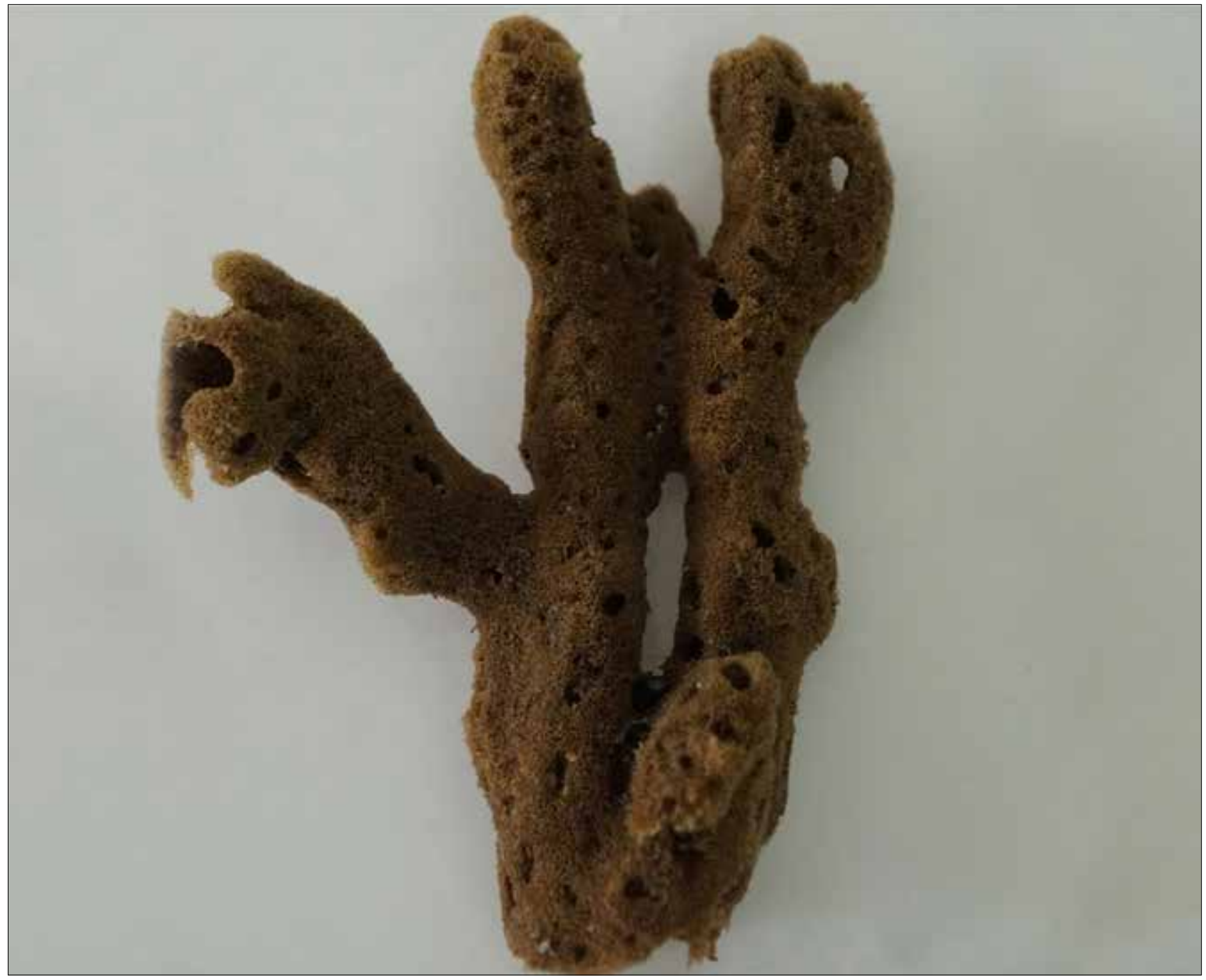

Fig. 4. Hyattella intestinalis 3 (Lamarck, 1814) CMFRI DNR No. BA.1.1.2.9.4 
Hyattella intestinalis was originally described by Lamarck (1814) as Spongia intestinalis. After a series of genera transfers it was finally assigned in Hyattella intestinalis. In 1881, Carter described Hircinia clathrata from the Gulf of Mannar ecosystem and renamed as Cateriospongia clathrata and Hyattella murrayi Lendenfeld 1889 for the sponge collected from East Indies. Several authors, from different parts of the world described the species in different names.

\section{Material examined}

1. Hyattella intestinalis 1: CMFRI.DNR No. BA.1.1.2.9 (Fig.2) Muttom, Kanyakumari, Tamilnadu (Lat: $8^{\circ} 7^{\prime} 20.07 " N$, Long: 77¹8'45.63"E), 10.11.2018, Gillnet sample (No.MT 53) deposited in the Museum of National Biodiversity Repository, CMFRI, Kochi, India.

2. CMFRI.DNR No. BA1.1.2.9.1 one fragment in Ethanol, deposited in the Museum of National Biodiversity Repository, CMFRI, Kochi, India.

3. Hyattella intestinalis 2: CMFRI.DNR No. BA.1.1.2.9.2 (Fig.3) Muttom, Kanyakumari, Tamilnadu (Lat: $8^{\circ} 7^{\prime} 20.07^{\prime \prime} N$, Long: 77¹8'45.63"E), 10.11.2018, Gillnet sample (No.MT 71) deposited in the Museum of National Biodiversity Repository, CMFRI, Kochi, India.

4. CMFRI.DNR No. BA.1.1.2.9.2.3, one fragment in Ethanol, deposited in the Museum of National Biodiversity Repository, CMFRI, Kochi, India.

5. Hyattella intestinalis 3: CMFRI.DNR No.BA.1.1.2.9.4 (Fig.4), Muttom, Kanyakumari, Tamilnadu (Lat: $8^{\circ} 7^{\prime} 20.07^{\prime \prime} \mathrm{N}$, Long: 77 18'45.63"E), 10.11.2018, Gillnet sample (No.MT 50), deposited in the Museum of National Biodiversity Repository, CMFRI, Kochi, India.

6. CMFRI.DNR No. BA.1.1.2.9.5 one fragment in Ethanol, deposited in the Museum of National Biodiversity Repository, CMFRI, Kochi, India.

Description: Sponge with simple, cylindrical branches and hollow body. Overall size of sponge with a height of $8 \mathrm{~cm}$, width of base $6 \mathrm{~cm}$. The finger height $3-6 \mathrm{~cm}$ and wall thickness $0.1-0.3 \mathrm{~cm}$. The wall thickness of lamella is $0.2 \mathrm{~cm}$ and wall diameter is $0.8 \mathrm{~cm}$. Hollow tubular with branching ends. Aereolated surface uneven, branching erect with branch length of 2-6 cm. They are attached directly to the substrate. Oscules evenly scattered over the surface producing porous reticulated appearance, mainly on the apex of the sponge digits. Oscule diameters $0.1-1.0 \mathrm{~cm}$. Ostia minute, dispersed over external surface. Consistency firm, compressible and difficult to tear, digitiform with large widely tapering surface processes.

Skeleton: Well-developed network of fibres with primary, secondary and tertiary fibres. The main skeleton consists of reticulation of sponge fibres often organised into primary, secondary and tertiary networks. Fibres are homogenous in the cross section.

Hyattella intestinalis 1: Primary fibres are 39.33- 52.0 $\mu \mathrm{m}$ diameter (Fig. 5A-B) cored with small particles of sand. Uncored secondary fibres $14.05-21.9 \mu \mathrm{m}$ diameter (Fig.5C). The tertiary fibres, $7.3-11.28 \mu \mathrm{m}$ in diameter (Fig. 5D).

Hyattella intestinalis 2: Primary fibres are $73.03-91.72 \mu \mathrm{m}$ diameter (Fig. 6A) cored with small particles and sand. Uncored secondary fibres, 32.64-52.00 $\mu \mathrm{m}$ diameter (Fig.6B). Tertiary fibres present.

Hyattella intestinalis 3: Primary fibres are $55.66-93.51 \mu \mathrm{m}$ diameter (Fig. 7A-B) cored with small particles and sand. Uncored
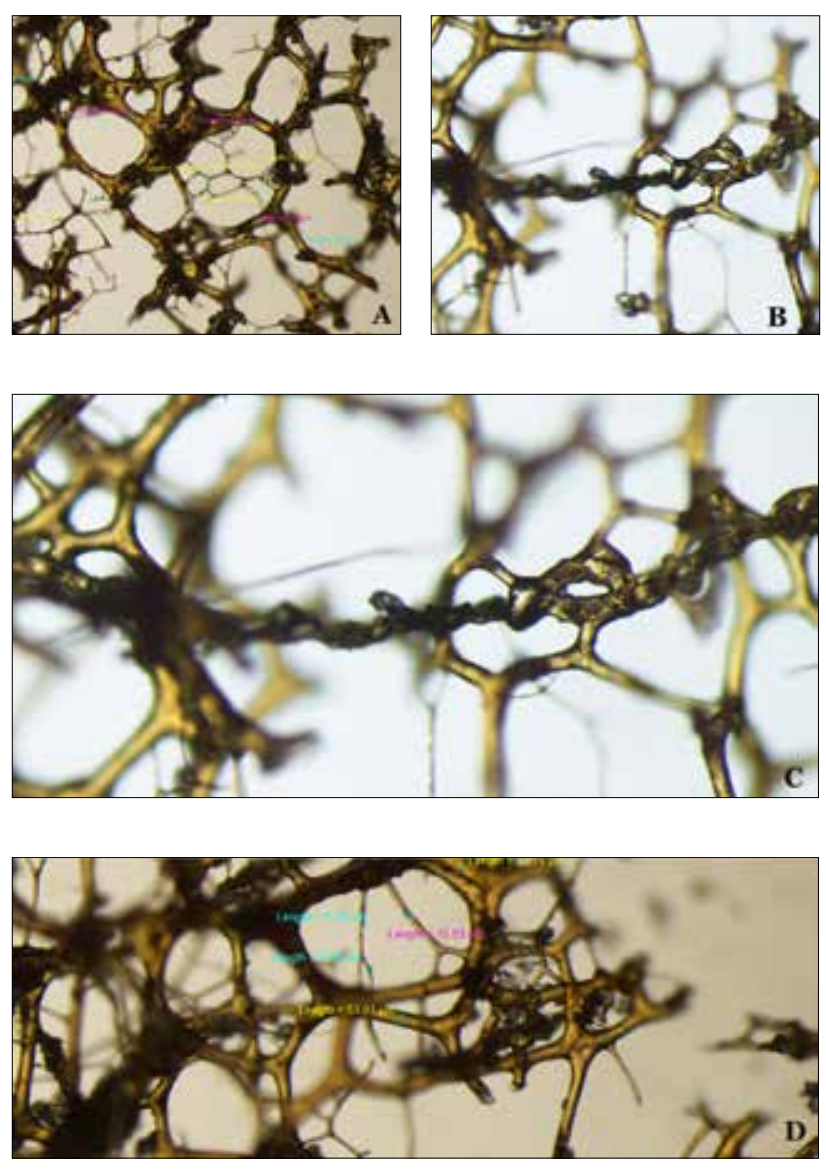

Fig. 5. A. Fibre skeleton (cross section) of Hyattella intestinalis 1 B. Cored primary fibres, C. Primary fibres in high power, D. Primary, secondary \& tertiary fibres (longitudinal section) 

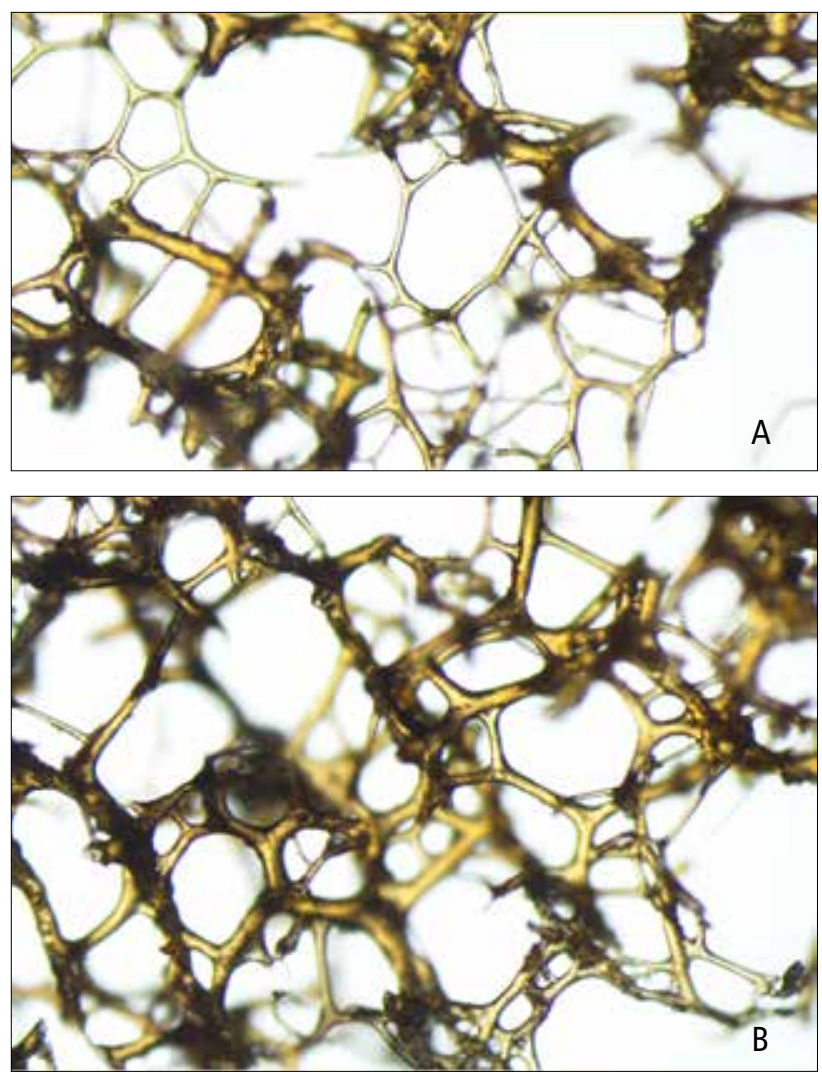

Fig. 6. A. Fibre skeleton (cross section) of Hyattella intestinalis 2 B. Fibre skeleton (longitudinal section)

secondary fibres, 16.37-45.77 $\mu \mathrm{m}$ diameter (Fig. 7C-D). Tertiary fibres present (Fig. 7E).

Distribution: Known from Gulf of Mannar, Palk Bay (Thomas, 1986), Mandapam, Vedalai, Shingle Island, Adiaman beach, Manauli Island (Sivaleela, 2014), Muttom (present study) of Tamilnadu state of India.

Remarks: Past literature review revealed that at least three type species i.e. Hippospongia intestinalis (Lamarck, 1814), USNM 7689, USNM 8721 (Holotype), Smithsonian National Museum of Natural History, (locality: Indian Ocean), Spongia intestinalis Lamarck, 1814, MNHN DT (Holotype) 584, Museum National d'Histoire Naturelle, Paris, (locality: Indian Ocean) and Hippospongia clathrata (Carter, 1881) BMNH 1920.12.9.46 (Holotype), British Museum of Natural History, (locality: Indian Ocean) were reported during 1800s. Dendy (1905) collected several samples of Hippospongia intestinalis (Lamarck, 1814) with the characters like elongated tubular form, perforated walls, conulose surface, irregular amber coloured skeleton from Gulf of Mannar and Ceylon seas. Later this species were synonymized as Hyattella intestinalis (Lamarck, 1814). Dendy (1916) reported species Hippospongia clathrata (Carter, 1881) (= Hyattella intestinalis (Lamarck, 1814) from Okha (Gujarat,
India) of the Northern Arabian Sea. The present material agrees with the description of Hyattella intestinalis (Lamarck, 1814) and the later reports three from the Gulf of Mannar Ecosystem (Dendy, 1905, Thomas, 1986, Sivaleela, 2014). All these studies have been reported the characters like elongated tubular form, walls perforated with openings, irregular, amber coloured fibres, surface is conulose (Dendy, 1905, Thomas, 1986) and minutely conulose, oscules terminal and texture hard (Sivaleela, 2014). Considering the morphological similarities and wide distribution pattern of the species reported from northern Arabian Sea (Okha) and the south-eastern Bay of Bengal (Gulf of Mannar) the present species from Muttom (Southern Arabian Sea) may be Hyattella intestinalis (Lamarck, 1814).
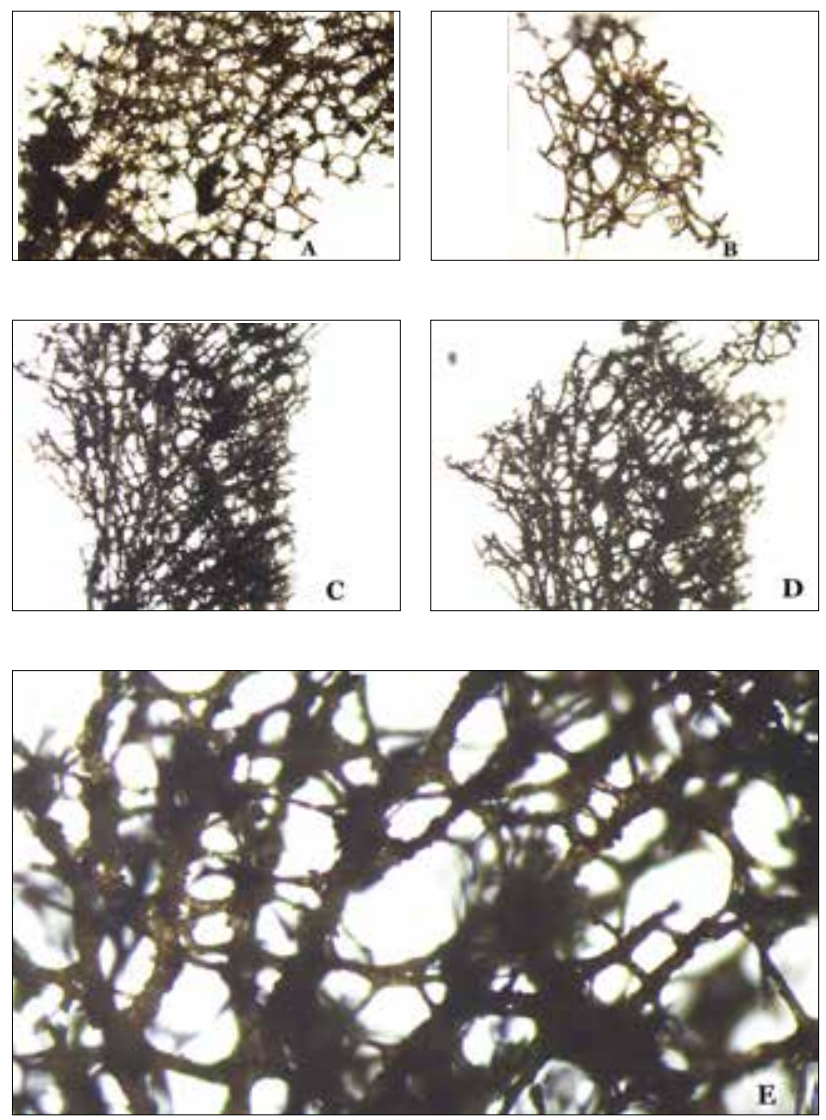

Fig. 7. A \& B. Fibre skeleton (cross section) of Hyattella intestinalis 3 C \& D. Fibre skeleton (longitudinal section), E. Longitudinal section in high power.

\section{Hyattella repandus sp. nov.}

(Fig. 8A-C, 9, Table 1)

\section{Material examined}

Holotype: CMFRI.DNR No. BA.1.1.2.8 (Fig.8A-C), Vedalai, Ramanathapuram, Tamilnadu (Lat: $9^{\circ} 15^{\prime} 50.33^{\prime \prime} \mathrm{N}$, Long: $79^{\circ}$ 

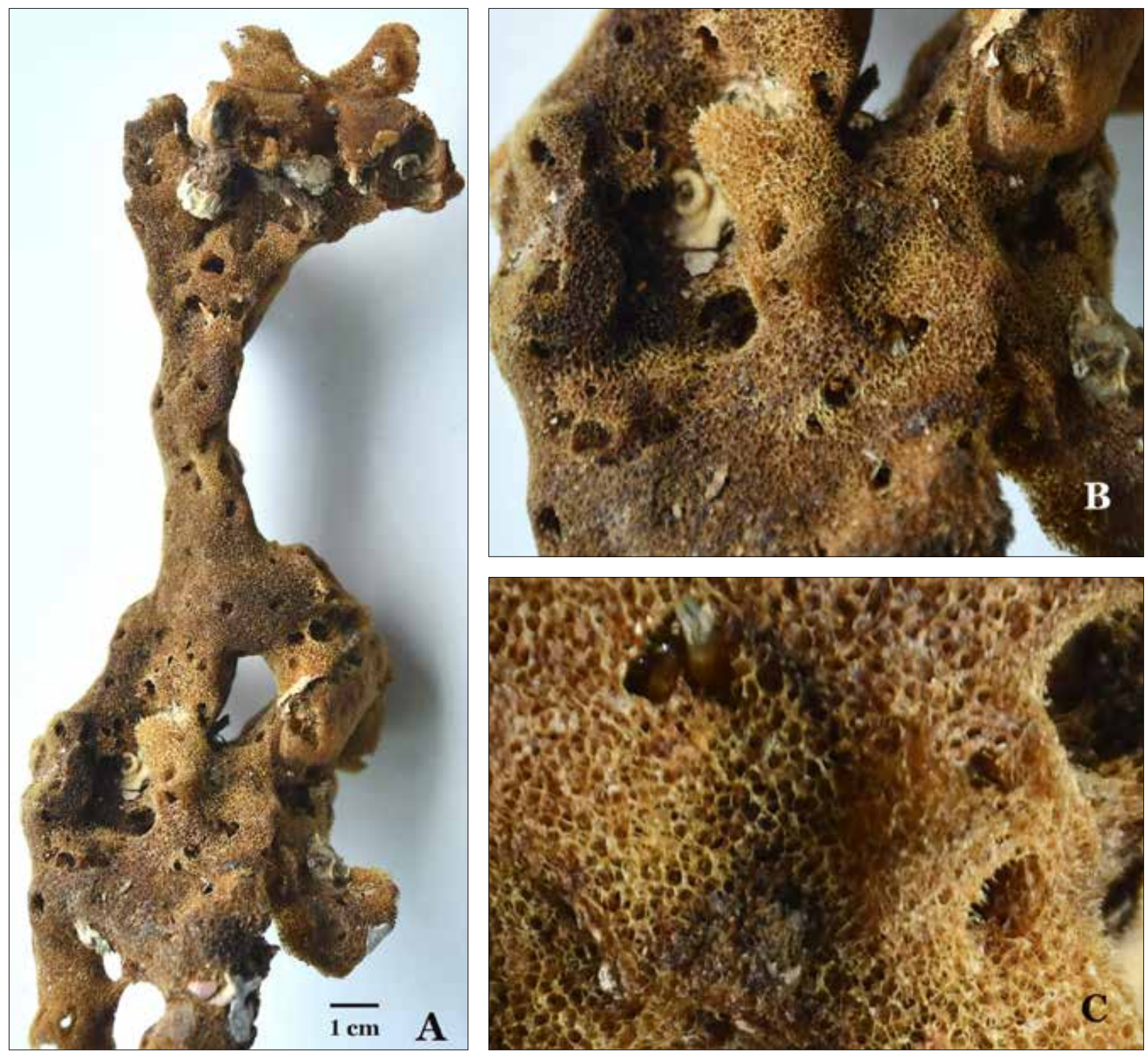

Fig. 8. A-C. Hyattella repandus sp. nov. Holotype, CMFRI DNR No. BA.1.1.2.8

6'24.02"E), 06.05.2019, Hand picking (No.VD 12), deposited in the Museum of National Biodiversity Repository, CMFRI, Kochi, India. ZooBank registration number as per the new Nomenclature Act: http://zoobank.org/urn:Isid:zoobank.org:act:C5660E6A6807-4EE9-A5C7-D0EEC46DC27F.

Paratype: 1. CMFRI.DNR No. BA.1.1.2.8.1, Vedalai, Ramanathapuram, Tamilnadu (Lat: 9 $9^{\circ} 15^{\prime} 50.33^{\prime \prime} \mathrm{N}$, Long: $\left.79^{\circ} 6^{\prime} 24.02^{\prime \prime} \mathrm{E}\right)$, 06.05.2019, Hand picking, deposited in the Museum of National Biodiversity Repository, CMFRI, Kochi, India.

2. CMFRI.DNR No. BA 1.1.2.8.2, one fragment in ethanol, deposited in the Museum of National Biodiversity Repository, CMFRI, Kochi, India.
Description: Hollow, tubular with branching ends with a size of $19.5 \mathrm{~cm}$. There are many independent tubes from the base. The colour is brownish. Surface is uneven and irregularly folded. They are attached to the substrate directly. Oscules are distributed all over the body with a diameter of $0.5 \mathrm{~cm}$. Consistency firm, compressible and difficult to tear.

Skeleton: Fibre network is the main skeleton and it has primary, secondary and tertiary fibres. Primary fibres are 79.81- 110.1 $\mu \mathrm{m}$ in diameter and cored (Fig. 9A-B) with small particles and sands. Uncored secondary fibres, 38.8-47.5 $\mu \mathrm{m}$ in diameter (Fig. 9C-D) well developed and make a complex mesh. Tertiary fibres are also present with diameter of 17.39-18.63 $\mu \mathrm{m}$ (Fig. 9 $\mathrm{E}-\mathrm{F})$. The distance between two conules is $396.81 \mu \mathrm{m}$. 

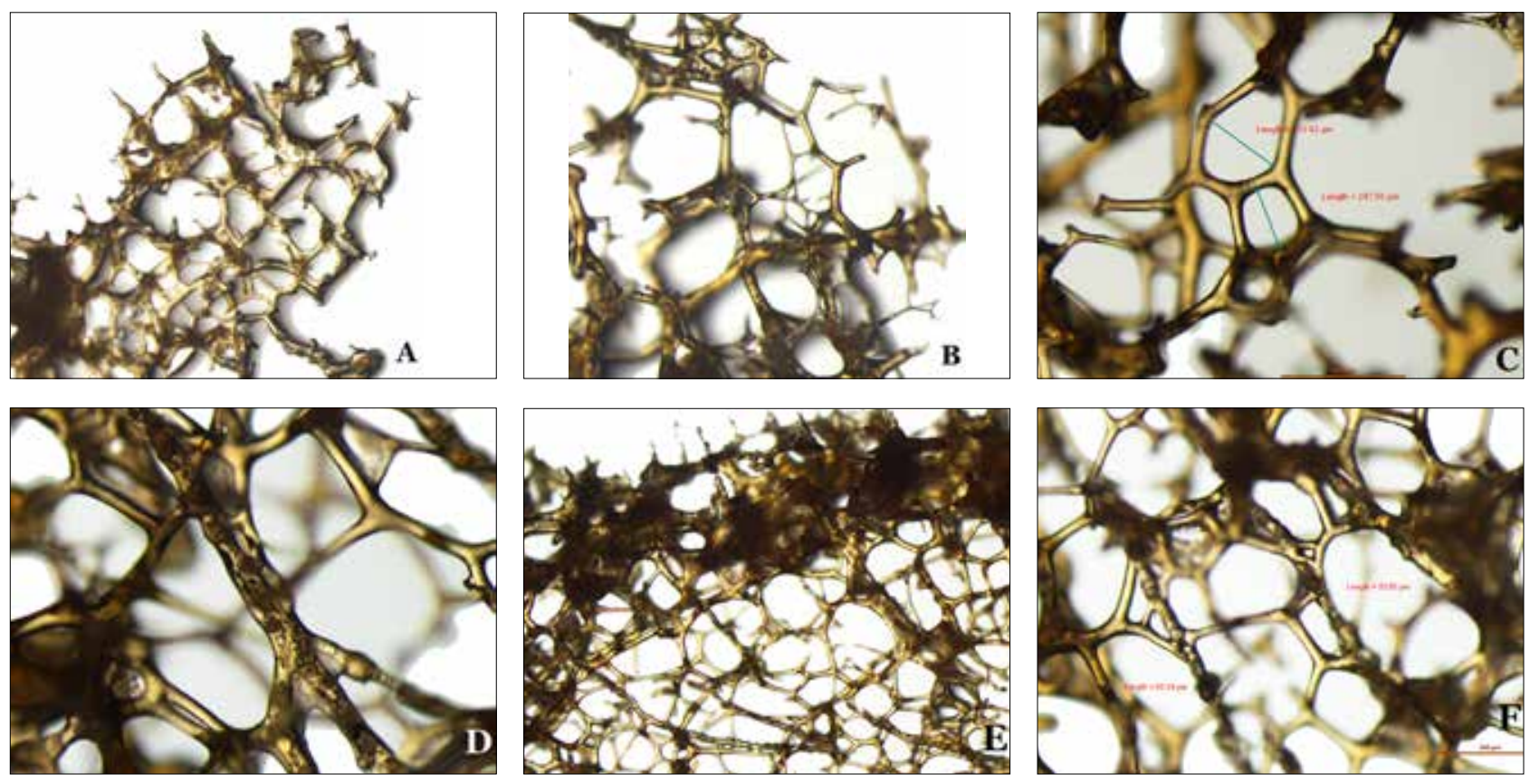

Fig. 9. A. Fibre skeleton (cross section) of Hyattella repandus sp. nov, B \& C. Cross section in high power, D. Primary fibre, E -F. Longitudinal section

Distribution: Known from Vedalai in Ramanathapuram of Gulf of Mannar of Tamilnadu state of India.

Etymology: The species name repandus in Latin refers to curved upwards or turned up shape of the sponge.

Remarks: The morphological characteristics of the original species description of Hyattella intestinalis (Lamarck, 1814) agree with those of the present species Hyattella repandus $\mathrm{n} . \mathrm{sp}$. in the general body pattern only. In general the present species Hyattella repandus n.sp., can be grouped $H$. intestinalis, $H$. tubaria, $H$. sinuosa and $H$. meander which are encrusting, pedunculate sponges with a basal mass from which arise irregularly curved cylindrical processes on an average $30 \mathrm{~mm}$ thick. But the Hyattella repandus n.sp. differ in branching pattern, width of the primary and secondary fibers and thickness of body wall with other congeners. Hyattella repandus n.sp. has hollow tubular with branching ends with thicker diameter of fibers but differs in having hollow tubular branches, smaller diameter of fibers in Hyattella macrophylla n.sp. has flattened base with narrowing at the tip in Hyattella foliata n. sp., arborescent bushy in Hyattella vedalainensis n.sp., arborescent bushy and globate massive in $H$. oblongus. n.sp. Considering the extend of internal differences between the other species, a new species Hyattella repandus is erected presently from Gulf of Mannar.

\section{Hyattella macrophylla sp. nov.}

(Fig.10 A-C, 11, Table 1)

\section{Material examined}

Holotype: CMFRI.DNR No. BA.1.1.2.10 (Fig.10A-C), Chetlat, Lakshadweep (Lat: $11^{\circ} 41^{\prime} 28.36^{\prime \prime} \mathrm{N}$, Long: $\left.72^{\circ} 42^{\prime} 13.72^{\prime \prime} \mathrm{E}\right)$, 26.09.2019, Skin dive collection (CHT 8), deposited in the Museum of National Biodiversity Repository, CMFRI, Kochi, India. ZooBank registration number as per the new Nomenclature Act: http://zoobank.org/urn:Isid:zoobank.org:act:FBF044EA-A89B4706-8C7E-E459DE9CDEOF

Paratype: 1. CMFRI.DNR No. BA.1.1.2.10.1, Chetlat, Lakshadweep (Lat: $11^{\circ} 41^{\prime} 28.36^{\prime \prime} \mathrm{N}$, Long: $\left.72^{\circ} 42^{\prime} 13.72^{\prime \prime} \mathrm{E}\right)$, 26.09.2019, Skin dive collection, deposited in the Museum of National Biodiversity Repository, CMFRI, Kochi, India.

2. CMFRI.DNR No. BA.1.1.2.10.2, one fragment in ethanol in the Museum of National Biodiversity Repository, CMFRI, Kochi, India.

Description: Encrusting, hollow, uneven shaped, branches arising from the base. They are directly attached to the substratum, encrusting with molluscan shells and corals. The colour is yellowish. The surface is uneven and meandering. Conules are present in the body. The distance between two conules is $962.80 \mu \mathrm{m}$. Oscules distributed all over the body. Consistency tough, slightly compressible and tough to tear. 

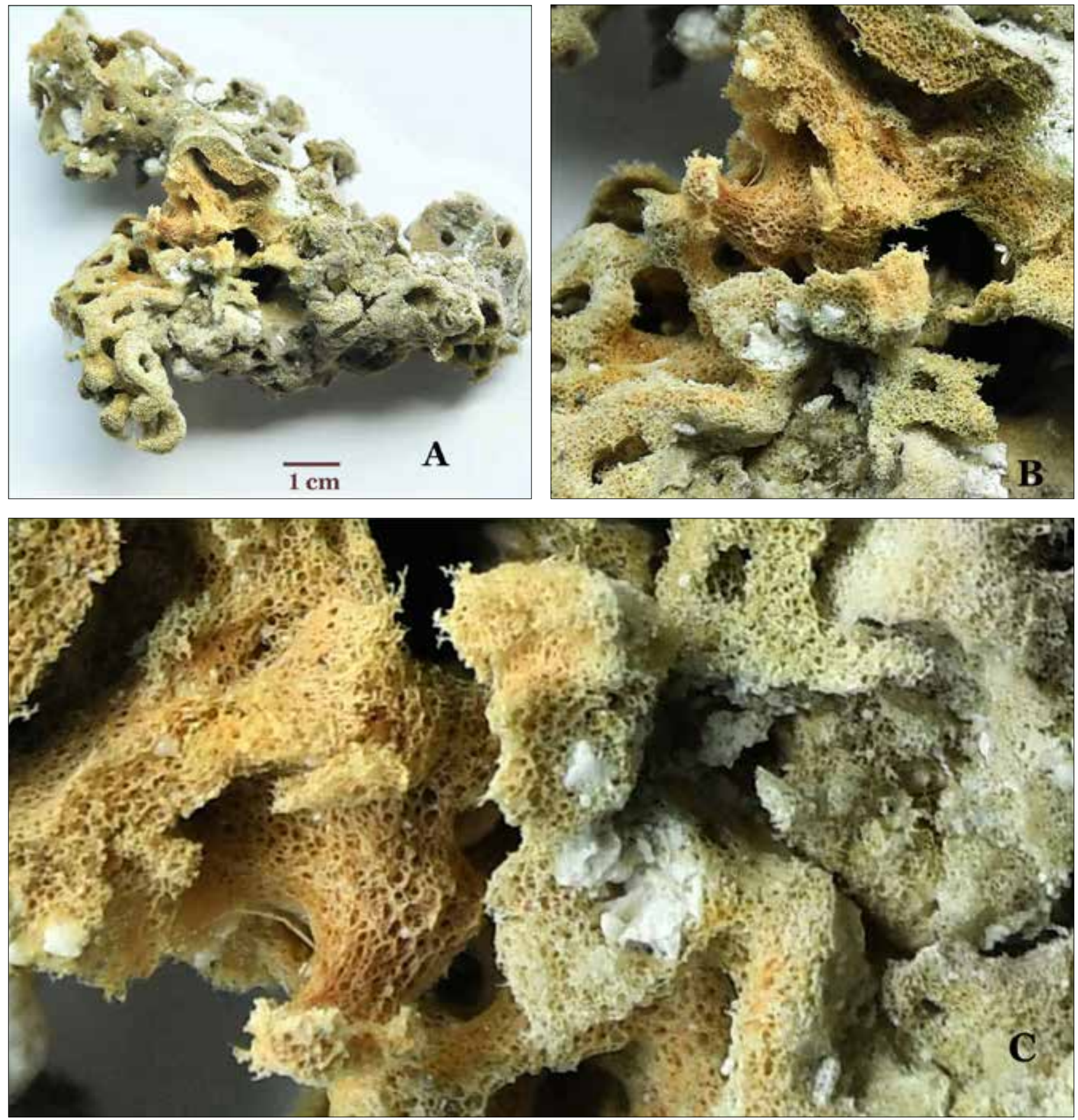

Fig. 10. A. Hyattella macrophylla sp. nov. Holotype, CMFRI DNR No. BA. 1.1.2.10, B \& C. Enlarged view of specimen

Skeleton: Fibre network is the main skeleton and it has primary and secondary fibres. Primary fibres are mainly cored and few are uncored (Fig. $11 \mathrm{~A}$ ). The cored and uncored primary fibre, $36.23 \mu \mathrm{m}$ and 54.31- 57.08 $\mu \mathrm{m}$ in diameter respectively (Fig. 11 B). Similarly, the secondary fibres also cored and uncored. The cored secondary fibres are $14.86-23.16 \mu \mathrm{m}$ in diameter (Fig. 11C).

Distribution: Known from Chetlat, Lakshadweep of India.
Etymology: The species name macrophylla in Latin refers to similarity with the structure of leaf.

Remarks: Hyattella macrophylla sp. nov. is an encrusting sponge, with hollow leaf-like bumps. With uneven surface with folding. This is a similar trait to Hyattella meander Lendenfeld, 1889 described as irregular, ramified, horizontally expanding sponge. Although, they differ as the sponge body irregular, surface smooth, presence of small digitate process, fibres close 

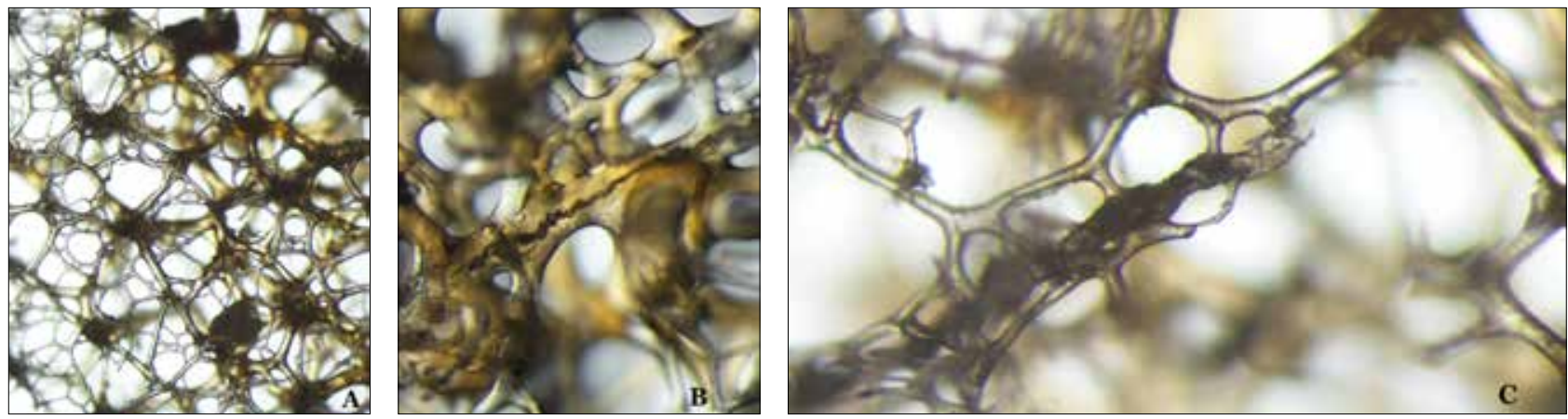

Fig. 11. A \& B. Fibre skeleton (cross section) of Hyattella macrophylla sp. nov, C. Cross section in high power
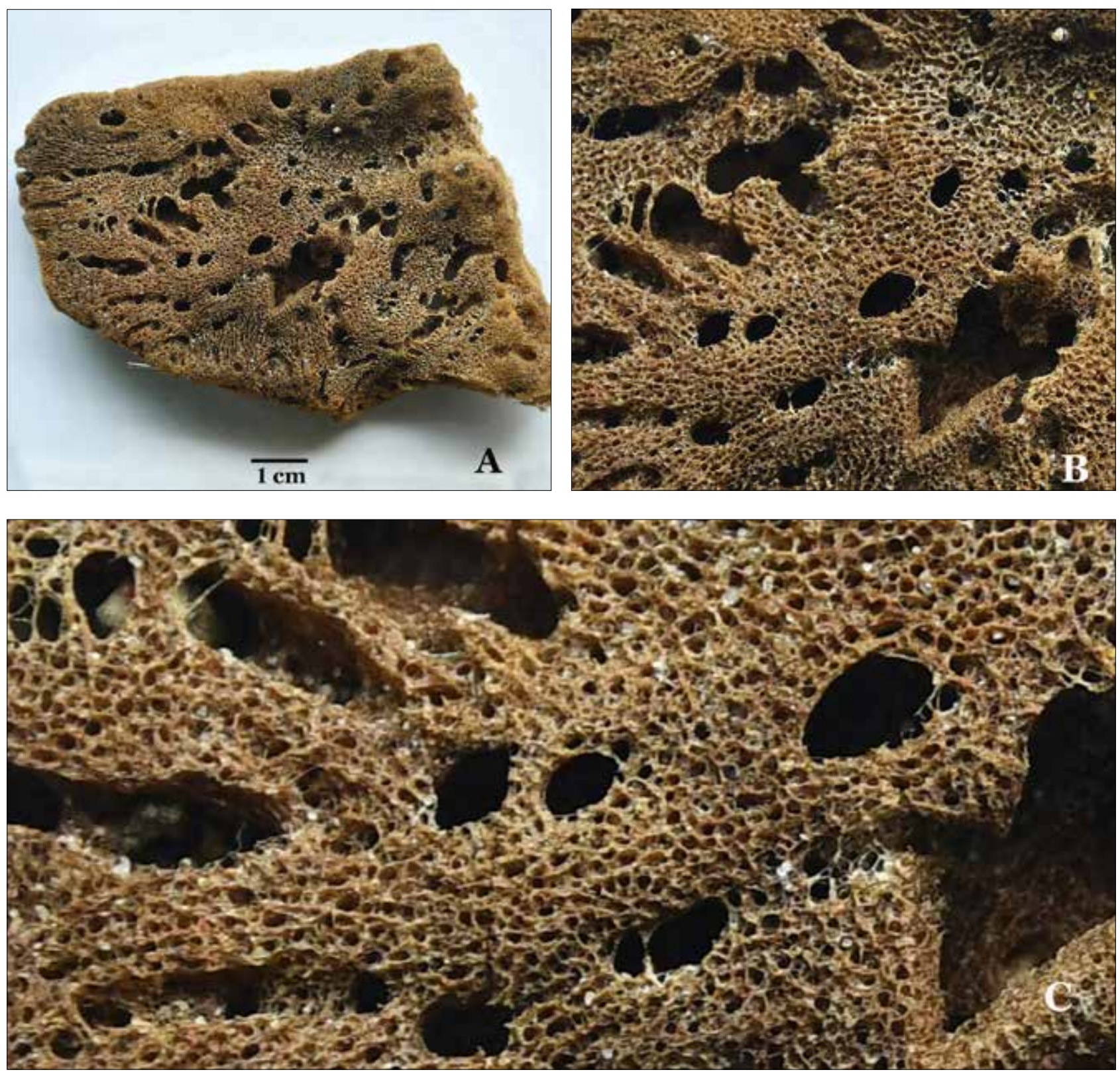

Fig. 12. A. Hyattella foliata sp. nov. Holotype, CMFRI DNR No. BA.1.1.2.14, B-C. Enlarged view of specimen 
together and form perforated plates, dark amber colour in dry condition in Hyattella meander. But in Hyattella macrophylla n.sp., sponge arises from the base and expands in the upper part, primary and secondary fibres form polygonal and circular networks, contains plenty of coral parts and shells of molluscs both in the external and internal parts of the sponge body, dull white colour in dry condition.

Hyattella macrophylla $\mathrm{n}$. sp. is distinguished by a network of primary fibres and secondary fibres cored and uncored both in primary and secondaries. The new species also shows thinner width for both primary $36.23-57.06 \mu \mathrm{m}$ and secondary fibers 14.86-57.08 $\mu \mathrm{m}$ than the other Hyattella spp. Considering the differences from, Hyattella meander, we describe Hyattella macrophylla as a new species to the genus Hyattella.

\section{Hyattella foliata sp. nov.}

(Fig. 12 A-C, 13 Table 1)

\section{Material examined}

Holotype: CMFRI.DNR No. BA.1.1.2.14 (Fig.12 A-C), Mandapam, Rameswaram, Tamilnadu (Lat: $9^{\circ} 16^{\prime} 17.28^{\prime \prime} \mathrm{N}$, Long: $79^{\circ}$ 7'53.71"E), 21.07.2018, Hand picking (MD 13) deposited in the Museum of National Biodiversity Repository, CMFRI, Kochi, India. ZooBank registration number as per the new Nomenclature Act: http://zoobank.org/urn:Isid:zoobank.org:act:83E79DF9E90B-4137-9EDF-F26704F07DA6

Paratype: 1. CMFRI.DNR No.BA.1.1.2.14.1, Mandapam, Rameswaram, Tamilnadu (Lat: 9 ${ }^{\circ} 16^{\prime} 17.28^{\prime \prime} \mathrm{N}$, Long: $79^{\circ}$ 7'53.71"E), 21.07.2018, Hand picking, deposited in the Museum of National Biodiversity Repository, CMFRI, Kochi.

2. CMFRI.DNR No.BA.1.1.2.14.2, one fragment in ethanol in the Museum of National Biodiversity Repository, CMFRI, Kochi.

Description: Encrusting sponge with a flattened base and narrowing tips. They are attached directly to the substratum or shells. Sponge has a height of $9 \mathrm{~cm}$ and with a base width of $7 \mathrm{~cm}$, wall diameter of $0.6 \mathrm{~cm}$ and wall thickness of $0.2-0.4$ $\mathrm{cm}$. Specimens are in wood colour. The walls of the sponge hollow. Conules are present in the body. They have small oscules on apex. Small ostia present all over the body. They are tough incompressible and difficult to tear.

Skeleton: They have well developed and strong network of the skeleton, and it has primary fibres, secondary fibres and tertiary fibres (Fig.13A-B). Primary fibres are curved with a width of 46.10-75.61 $\mu \mathrm{m}$ (Fig. 13C) and filled with sand and molluscan parts (Fig.13D). Secondary fibres are also cored with
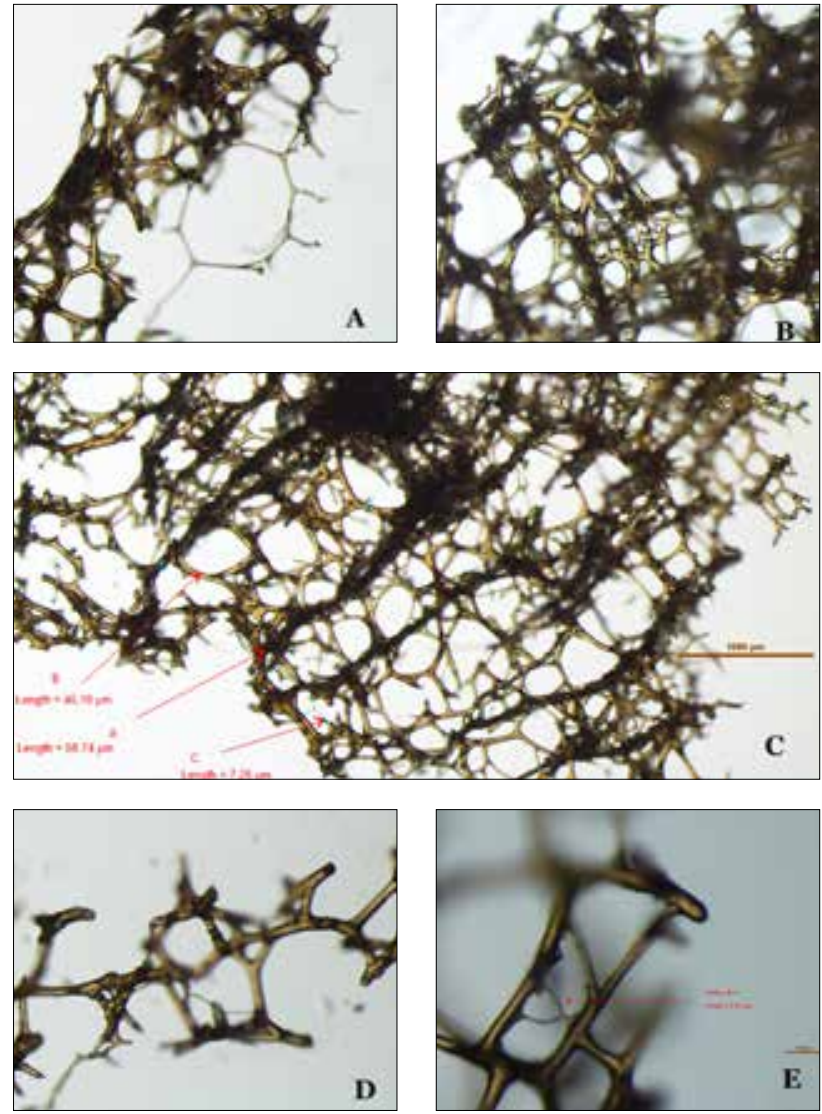

Fig. 13. A-B. Fibre skeleton (cross section) of Hyattella foliata sp. nov, C. Fibre skeleton (longitudinal section), D-E. Primary, secondary, tertiary fibres.

a width of 32.43-68.74 $\mu \mathrm{m}$ (Fig.13D). Tertiary fibres present with a width of 6.45-7.26 $\mu \mathrm{m}$ (Fig.13E).

Distribution: Known from Mandapam in Rameswaram of Gulf of Mannar, Tamilnadu, India.

Etymology: The species name foliata in Latin refers to similarity of two joined petals of a flower.

Remarks: Hyattella foliata n. sp. is distinguished by having a shape of flower petals attached together, while $H$. intestinalis and $H$. repandus n. sp. are encrusting and branched forms. Compared with even surface in $H$. intestinalis the surface in $H$. macropylla are uneven. The diameter of the primary fibres is thicker in $H$. foliata n. sp. compared with $H$. macrophylla n. sp. The diameter of the secondary fibres is also thicker in $H$. foliata n. sp. Compared with $H$. intestinalis, $H$. repandus n. sp., H. macrophylla n. sp. and other species of the genus Hyattella, the present species Hyattella foliata n.sp. have small oscules on apex. Considering the differences observed in this species, a new species Hyattella foliata $\mathrm{n}$. sp. is now being erected from Indian waters. 

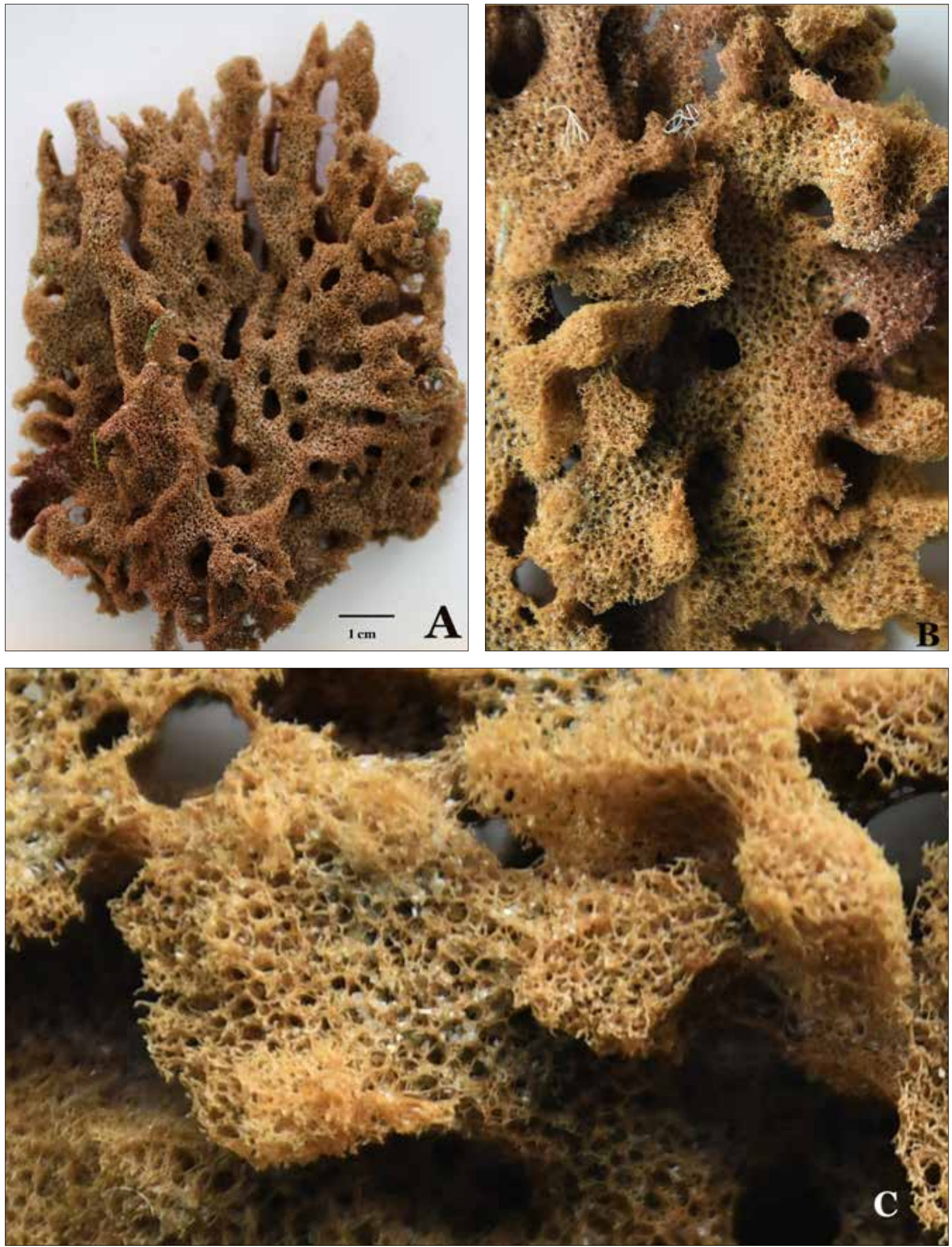

Fig. 14. A. Hyattella vedalainensis sp. nov. Holotype, CMFRI DNR No. BA.1.1.2.12, B-C. Enlarged view of specimen 
Hyattella vedalainensis sp. nov.

(Fig. 14 A-C, 15, Table 1)

\section{Material examined}

Holotype: CMFRI.DNR No. BA.1.1.2.12 (14 A-C), Vedalai, Ramanathapuram, Tamilnadu (Lat: $9^{\circ} 15^{\prime} 48.48^{\prime \prime} \mathrm{N}$, Long: $79^{\circ}$ 6'24.00"E), 21.07.2018, Hand picking (No.VD 23), deposited in the Museum of National Biodiversity Repository, CMFRI, Kochi, India. ZooBank registration number as per the new Nomenclature Act: http://zoobank.org/urn:Isid:zoobank.org:act:379C39E35AAA-4F79-B332-89D8B1ADA269

Paratype 1: CMFRI.DNR No. BA.1.1.2.12.1, Vedalai, Ramanathapuram, Tamilnadu (Lat: 9 ${ }^{\circ} 15^{\prime} 48.48^{\prime \prime} \mathrm{N}$, Long: $79^{\circ}$ 6'24.00"E), 21.07.2018, Hand picking, deposited in the Museum of National Biodiversity Repository, CMFRI, Kochi, India.

2. CMFRI.DNR No. BA.1.1.2.12.2, one fragment in ethanol in the Museum of National Biodiversity Repository, CMFRI, Kochi, India.

Description: Encrusting, arborescent with distal tubes arising from the base. Cavernous body which is flattened in shape looks like anastomosing network of tubes. The specimen has a height of $10 \mathrm{~cm}$ and basal width of $8 \mathrm{~cm}$. The basal part is less in width, and it increases to middle and top part of the sponge. They are directly attached to the substrate. The colour is yellowish brown. Conules present in the body. Oscules are distributed all over the body. The oscule diameter is $0.2 \mathrm{~cm}$. They are soft compressible and easy to tear. It is more spongy and elastic.

Skeleton: It has rich fibre network and has primary and secondary fibres (Fig. 15A-B). Primary fibres are heavily cored, 118.07-103.74 $\mu \mathrm{m}$ in diameter (Fig.15C-F). The secondary fibres are $56.84 \mu \mathrm{m}$ in diameter (Fig.15D). Lots of sand and molluscan soft-shell particles were seen in the choanosome (Fig.15E).

Distribution: Known from Vedalai in Ramanathapuram of Gulf of Mannar, Tamilnadu, India.

Etymology: Species name "vedalainensis" in Latin is derived from the locality name Vedalai an ancient fishing village of Ramanathapuram district. Also the word 'Veda' in Sanskrit means knowledge and the four books on Vedas written in BC 1500.

Remarks: This encrusting, arborescent type of sponge is entirely new to the genus Hyattella. Unique characters of flattened type body, thicker width of primary fibres, presence of enormous amounts of sand and other particles in the sponge body makes it into a new species.
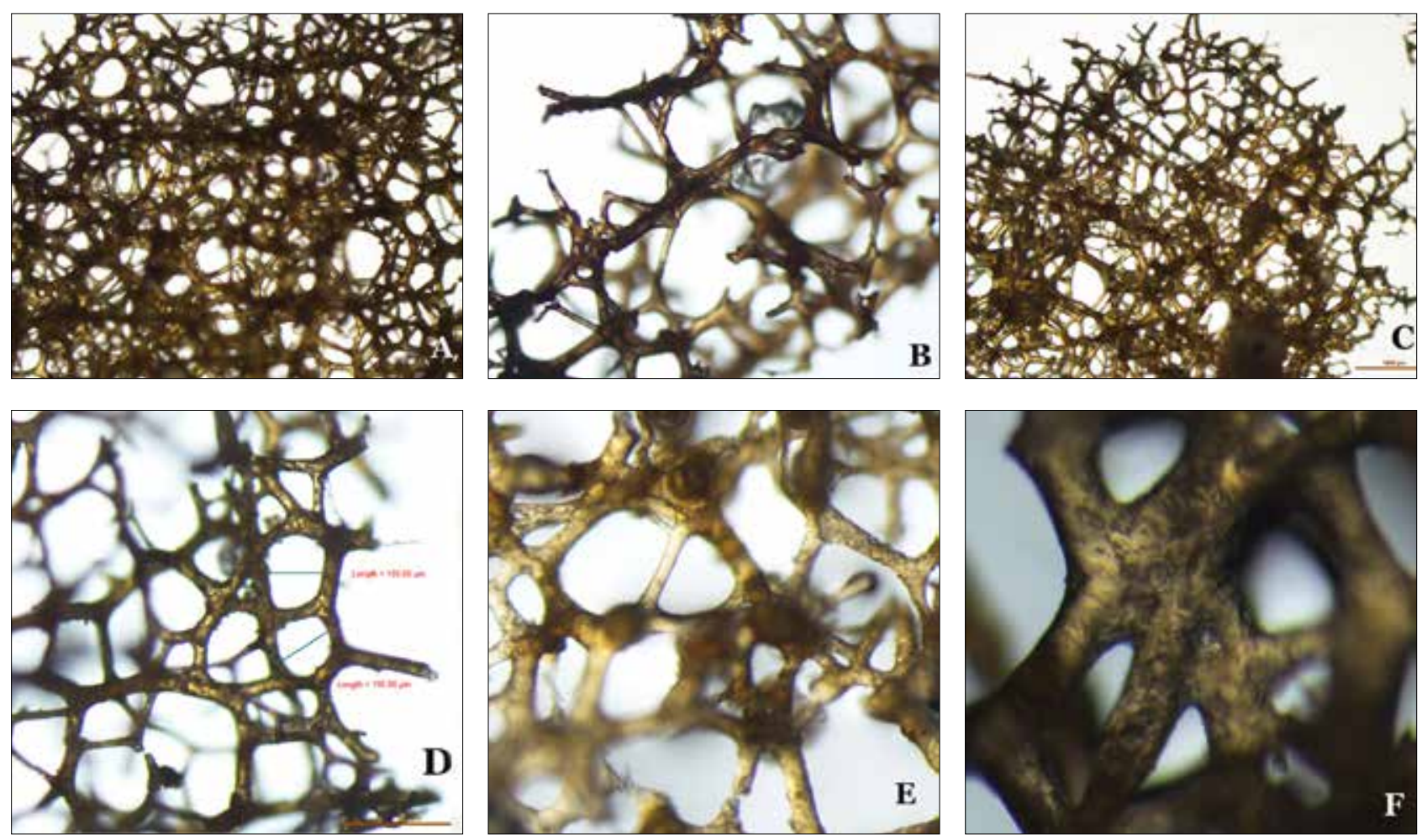

Fig. 15. A. Fibre skeleton (cross section) of Hyattella vedalainensis sp. nov, B. Primary fibres, C-D. Fibre skeleton (longitudinal section), E. Cross section in high power, F. Longitudinal section in high power. 

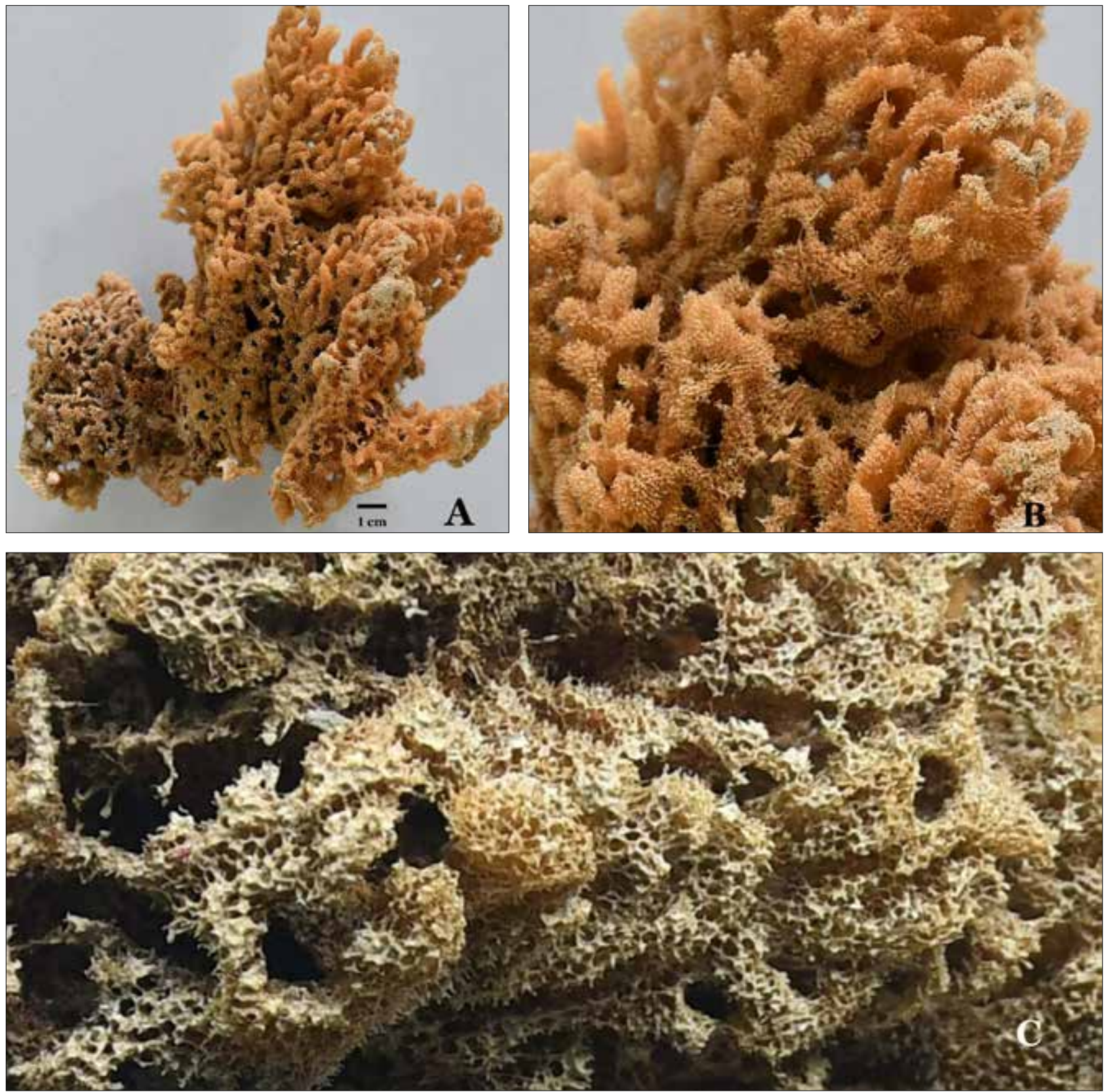

Fig. 16. A. Hyattella diffusa sp. nov. Holotype, CMFRI DNR No. BA.1.1.2.13, B-C. Enlarged view of specimen

Hyattella vedalainensis n.sp. differ from the other species of Hyattella specifically, H. intestinalis (Lamarck, 1814), H. foliata n.sp., $H$. repandus n.sp. and $H$. macrophylla n.sp. The oscules in $H$. vedalainensis $n . s p$. are small as well as the cavities of the external and internal body as compared to the other four species. $H$. vedalainensis n.sp. has an oval shaped mesh network while the other four species are nearly polygonal. $H$. vedalainensis n.sp. have thicker fiber diameters as compared to $H$. intestinalis (Lamarck, 1814) and H. macrophylla n.sp. H. vedalainensis n.sp. has densely cored primary fibers whereas coring is less in the case of $H$. macrophylla n.sp. and H. foliata n.sp.
Hyattella diffusa sp. nov.

(Fig. 16 A-C, 17, Table 1)

\section{Material examined}

Holotype: CMFRI.DNR No. BA.1.1.2.13 (Fig.16 A-C), Mandapam, Tamilnadu (Lat: 9 ${ }^{\circ} 16^{\prime} 17.26^{\prime \prime} \mathrm{N}$, Long: $\left.79^{\circ} 7^{\prime} 51.75^{\prime \prime E}\right), 21.07 .2018$, Hand picking (MD 2), deposited in the Museum of National Biodiversity Repository, CMFRI, Kochi, India. ZooBank registration number as per the new Nomenclature Act: http://zoobank. 
org/urn:Isid:zoobank.org:act:76482035-F13B-4AA8-96ADEEB7379A85BC

Paratype 1: CMFRI.DNR No.BA.1.1.2. 13.1, Mandapam, Tamilnadu (Lat: 9¹6'17.26"N, Long: 79 7'51.75"E), 21.07.2018, Hand picking, deposited in the Museum of National Biodiversity Repository, CMFRI, Kochi, India.

2. CMFRI.DNR No. BA.1.1.2.13.2, one fragment in Ethanol deposited in the Museum of National Biodiversity Repository, CMFRI, Kochi, India.

Description: Sponge with arborescent or bushy shape, with irregular branches in more than one plane (Fig. 16B). They are cavernous and hollow. Sponge body size decreases from the base to top and it is pointing towards the apex. The sponge height is $14.5 \mathrm{~cm}$, the basal width $13 \mathrm{~cm}$, and wall thickness $0.3 \mathrm{~cm}$. They are directly attached to the substrate and associated with bivalves and gastropod shells. Colour is yellowish brown. The surface is uneven with irregular folding. The oscules are large and circular with a diameter of $1 \mathrm{~cm}$. Minute ostia are present all over the body. They are compressible and easy to tear.
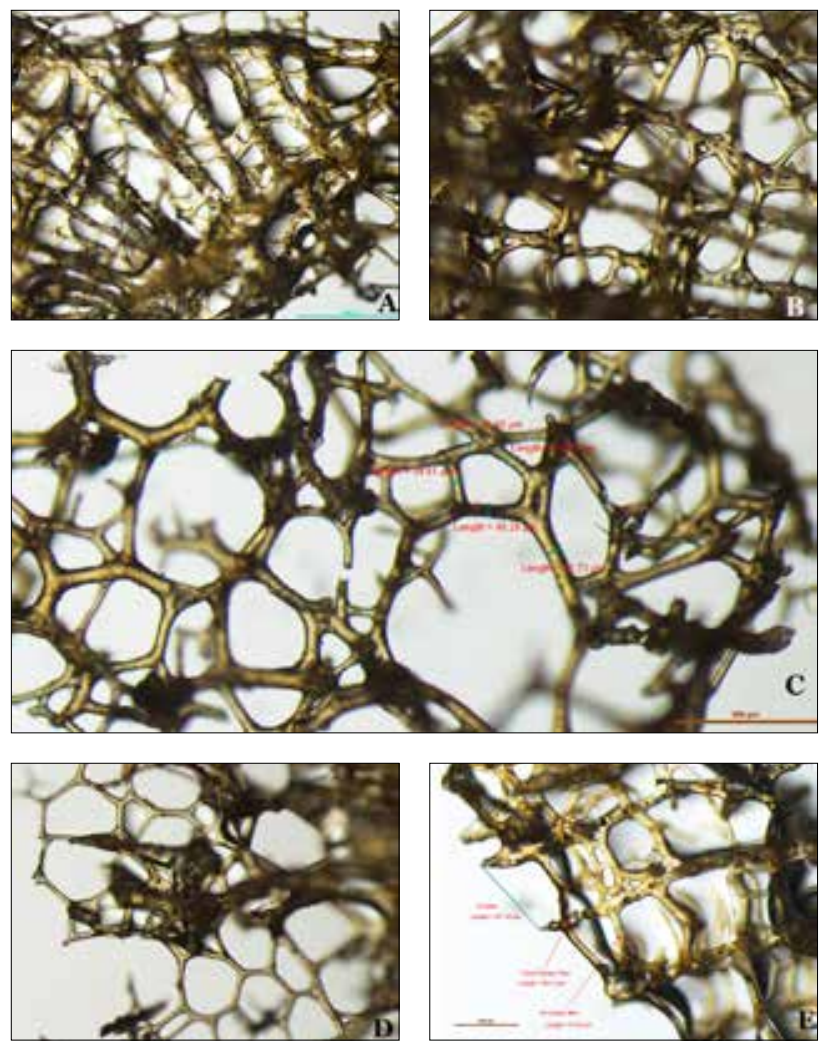

Fig. 17. A-B. Fibre skeleton (cross section) of Hyattella diffusa sp. nov, C. Cross section in high power, D \& E. Fibre skeleton (longitudinal section)
Skeleton: They are having very rich fibre network which has primary and secondary fibres only (Fig.17A-B). Primary fibres cored, 95.34-100.46 $\mu \mathrm{m}$ in diameter (Fig. 17C) filled with sand and molluscan shells. Secondary fibres, 34.81-63.6 $\mu \mathrm{m}$ in diameter (Fig. 17E). Tertiary fibres absent (Fig. 17D-E).

Distribution: Known from Mandapam in Gulf of Mannar of Tamilnadu, India.

Etymology: The species name diffusa in Latin refers to extending widely and it denotes the spread of small outgrowths throughout the body.

Remarks: Although Hyattella diffusa n.sp. shows few similarities with Hyattella sinuosa (Pallas, 1766), they are entirely different. The peculiar character of the present species such as arborescent, bushy, irregular branches in more than one plane makes it unique from $H$. sinuosa, which has an encrusting shape with digitate processes. The thicker width of the primary fibres $(95-100 \mu \mathrm{m})$ also makes it different from $H$. sinuosa that has 28-70 $\mu \mathrm{m}$ (Lendenfeld, 1889). Considering these unique characters of the present species, we describe it as a new species.

Past literature review revealed that several type species ie. Spongia sinuosa Pallas, 1766, BMNH 1882.10.17.35, (locality: Indian Ocean), Hippospongia sinuosa (Pallas, 1766), MNHN DT 655, Hippospongia decidua (Hyatt, 1877) MCZ, Hyattella arborea Lendenfeld, 1889, BMNH and Hyattella lamarcki Topsent, 1933 MNHN DT 655 were reported from different localities. Pallas (1766) described Spongia sinuosa and later changed through a series of revisions and finally transferred to the present accepted name of Hyattella sinuosa (Pallas, 1766). This include the reports of Hippospongia decidua (Hyatt, 1877) from Mascarene Islands, described two varieties of Hippospongia sinuosa (Pallas, 1766), Hippospongia sinuosa var decidua Hyatt, 1887 from Seychelles, Hyattella arborea Lendenfeld 1889 from Australia, Hyattella lamarcki Topsent, 1933 from Ambon, Indonesia and Hyattella decidua (Lendenfeld, 1889) from the North American coast and African coast.

H. diffusa n.sp. is an arborescent, small tubular branches compared with $H$. intestinalis, $H$. vedalainensis n.sp, $H$. macrophylla n.sp and $H$. foliata n.sp. The $H$. diffusa n.sp. is compressible and easy to tear as compared to the other five species. The diameter of the primary fibres is more in the $\mathrm{H}$. diffusa n.sp. as compared to $H$. foliata n.sp. H. macrophylla n.sp. and $H$. intestinalis. Considering the presence of Hyattella sinuosa doubtful in the Indian Ocean, the present species we got from Gulf of Mannar may be different one. 

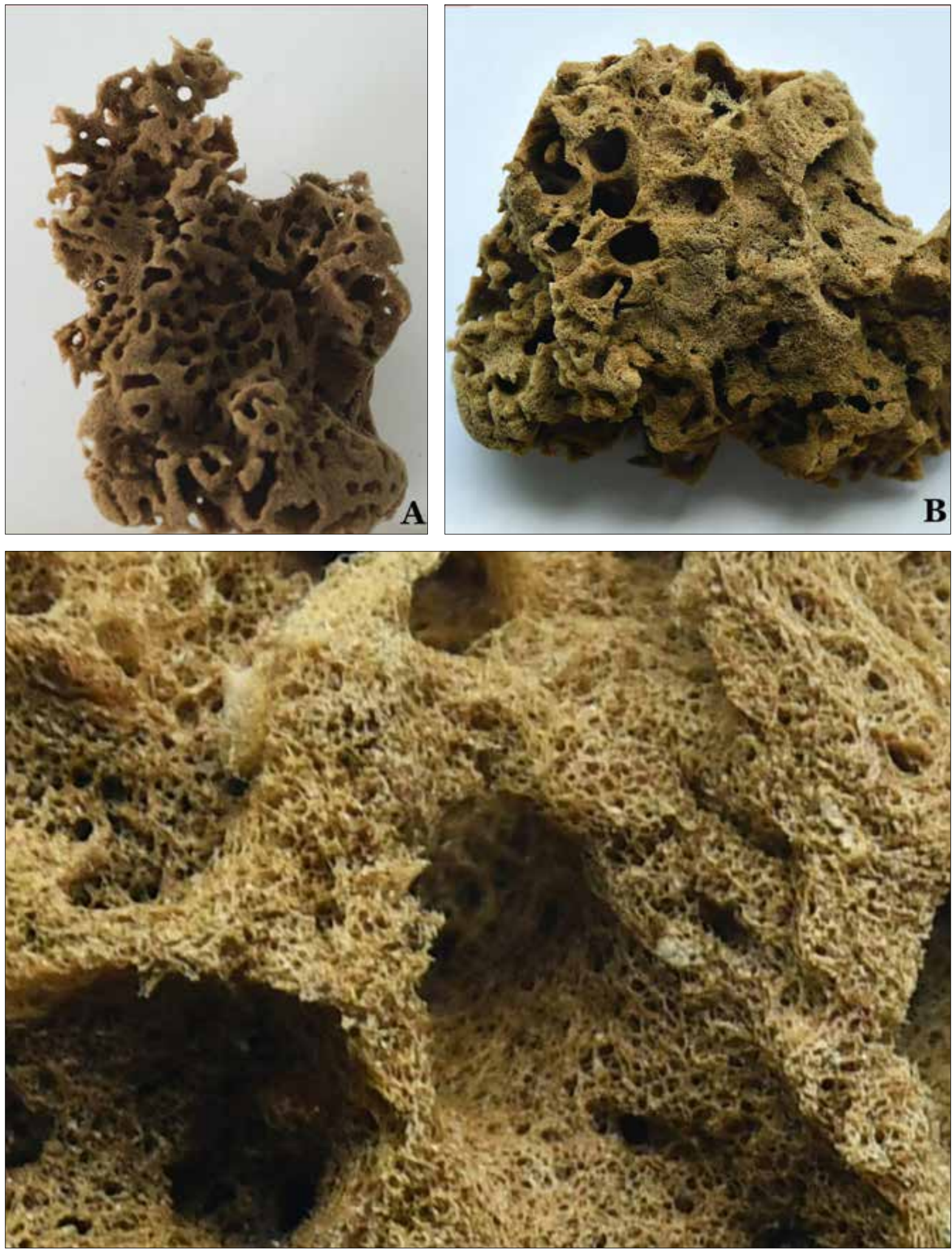

Fig. 18. A-B. Hyattella oblongus sp. nov. Holotype, CMFRI DNR No. BA.1.1.2.11, C. Enlarged view of specimen 
Hyattella oblongus sp. nov.

(Fig. 18 A-C, 19, Table 1)

\section{Material examined}

Holotype: CMFRI.DNR No. BA.1.1.2.11(Fig.18A-C), Muttom, Kanyakumari, Tamilnadu (Lat: $8^{\circ} 72^{\prime} 0.07^{\prime \prime} \mathrm{N}$, Long: $\left.77^{\circ} 18^{\prime} 45.63^{\prime \prime} \mathrm{E}\right)$, 17.10.2018, Gillnet sample (MT 32), deposited in the Museum of National Biodiversity Repository, CMFRI, Kochi, India. ZooBank registration number as per the new Nomenclature Act: http:// zoobank.urn:Isid:zoobank.org:act:AB32CE3B-A187-4FA6-8823EC44F3967B51

Paratype: 1. CMFRI.DNR No. BA.1.1.2.11.1, Muttom, Kanyakumari, Tamilnadu (Lat: $8^{\circ} 72^{\prime} 0.07^{\prime \prime} \mathrm{N}$, Long: $\left.77^{\circ} 18^{\prime} 45.63^{\prime \prime} \mathrm{E}\right)$, 17.10.2018, Gillnet sampling, deposited in the Museum of National Biodiversity Repository, CMFRI, Kochi, India.

2. CMFRI.DNR No. BA.1.1.2.11.2, one fragment in ethanol in the Museum of National Biodiversity Repository, CMFRI, Kochi, India.
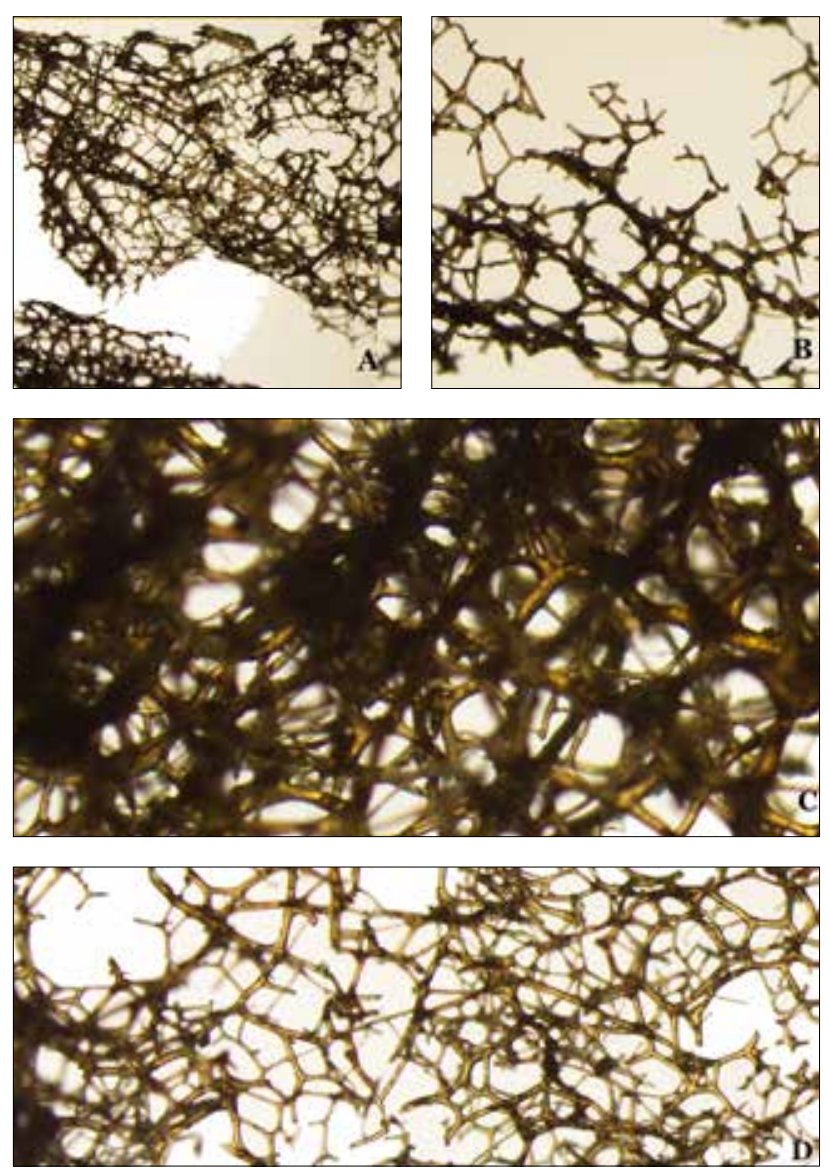

Fig. 19. A-B. Fibre skeleton (cross section) of Hyattella oblongus sp. nov, C-D. Fibre skeleton (longitudinal section)
Description: Species with globate and massive body, highly cavernous, whose cavities form irregular folds and small elongated projections. Surface is conulose, colour brownish. Oscules are small, evenly scattered with opening width of $1 \mathrm{~cm}$. Minute ostia scattered evenly on the surface. Consistency firm and barely compressible. Surface aerolated, uneven and opaque.

Skeleton: The main skeleton consists of reticulation of sponge fibres often organised into primary, secondary and tertiary networks. Primary fibres cored, 9.17-10.79 $\mu \mathrm{m}$ in diameter filled with small particles and sand (Fig.19A-B). Secondary fibres are 2.27-3.27 $\mu \mathrm{m}$ in diameter and tertiary fibres absent. Distance between two conules is $41.50 \mu \mathrm{m}$ (Fig.18A-B). Width of the polygon meshes in the primary fibres $35-45 \mu \mathrm{m}$.

Distribution: Known from Muttom in Kanyakumari district of Tamilnadu, India.

Etymology: The species name oblongus in Latin refers to shape of the cavities seen externally as well as internally and its elongated in shape.

Remarks: Hyattella oblongus n.sp. is very unique and different species from all other congeners already described from the genus Hyattella. At the same time several authors allocated it either to $H$. cribriformis, $H$. intestinalis and $H$. sinousa. However, we examined scrutiny of all these species and finally concluded that it is different from other congeners.

H. oblongus $\mathrm{n} . \mathrm{sp}$. is globate and massive in shape as compared to $H$. intestinalis, $H$. vedalainensis n. sp., $H$. macrophylla n. sp., $H$. diffusa n.sp. and $H$. foliata n.sp. The diameter of the primary fibres and secondary fibres are the smallest in H. oblongus n.sp. as compared to other six species. They are also the smallest compared to other Hyattella species worldwide. The presence of globate massive body makes it different from other members of the group. Small oscules are scattered all over the body with opening of $1 \mathrm{~cm}$, primary fibres with a width of 9-10 $\mu \mathrm{m}$ and secondary fibres $(2-3 \mu \mathrm{m})$ isolates this from other species. Hence, we describe it as a new species.

\section{Discussion}

The present description of six new species of the Genus Hyattella from Gulf of Mannar and the South West coast of India contributes to the unexplored species diversity of Indian Ocean. With this six new additions the total number of species from Indian Ocean becomes 12 including the already known Hyattella intestinalis (Lamarck, 1814); Hyattella meander Lendenfeld, 1889, Hyattella pertusa (Esper, 1794); Hyattella sinuosa (Pallas, 1766), Hyattella tubaria Lendenfeld, 1889 and Hyattella globosa Lendenfeld, 1889. The exact species composition of genus Hyattella has been 
Table 1. Comparisons of different Hyattella species obtained in the South west coast of India (present study)

\begin{tabular}{|c|c|c|c|c|c|c|c|c|}
\hline Sl.no & $\begin{array}{l}\text { Characters/ } \\
\text { Spp. }\end{array}$ & H.intestinalis & H.repandus n.sp. & $\begin{array}{l}\text { H.macrophylla } \\
\text { n.sp. }\end{array}$ & H.foliata n.sp. & H.vedalainensis n.sp. & H.diffusa n.sp. & H.oblongus n.sp. \\
\hline 1 & Shape & $\begin{array}{l}\text { Simple branch, } \\
\text { cylindrical digitate } \\
\text { branches }\end{array}$ & $\begin{array}{l}\text { Hollow, tubular with } \\
\text { branching ends }\end{array}$ & $\begin{array}{l}\text { Hollow tubular } \\
\text { branches }\end{array}$ & $\begin{array}{l}\text { Flattened base with } \\
\text { narrowing at the top }\end{array}$ & $\begin{array}{l}\text { Encrusting, } \\
\text { Arborescent, tubes }\end{array}$ & $\begin{array}{l}\text { Arborescent, bushy, } \\
\text { irregular branches }\end{array}$ & Globate, massive \\
\hline 2 & Attachment & $\begin{array}{l}\text { Directly to } \\
\text { substrate }\end{array}$ & Directly to substrate & $\begin{array}{l}\text { Directly to } \\
\text { substratum }\end{array}$ & $\begin{array}{l}\text { Attached directly to } \\
\text { substratum of shells }\end{array}$ & Directly to substrate & $\begin{array}{l}\text { Directly to substrate, } \\
\text { association with } \\
\text { shells }\end{array}$ & $\begin{array}{l}\text { To substrate } \\
\text { insinuating in to } \\
\text { cavities }\end{array}$ \\
\hline 3 & Oscule & $\begin{array}{l}\text { Small evenly } \\
\text { scattered over the } \\
\text { surface }\end{array}$ & $\begin{array}{l}\text { Distributed all over the } \\
\text { body, diameter } 0.5 \mathrm{~cm}\end{array}$ & $\begin{array}{l}\text { Distributed all } \\
\text { over the body }\end{array}$ & $\begin{array}{l}\text { Small oscules on } \\
\text { apex }\end{array}$ & Diameter- $0.2 \mathrm{~cm}$ & $\begin{array}{l}\text { Terminal oscule, } \\
\text { Diameter } 1 \mathrm{~cm}\end{array}$ & $\begin{array}{l}\text { Small, evenly } \\
\text { scattered oscule }\end{array}$ \\
\hline 4 & Consistency & $\begin{array}{l}\text { Tough, } \\
\text { compressible, } \\
\text { difficult to tear }\end{array}$ & $\begin{array}{l}\text { Firm, compressible, } \\
\text { difficult to tear }\end{array}$ & $\begin{array}{l}\text { Tough, slightly } \\
\text { compressible, } \\
\text { tough to tear }\end{array}$ & $\begin{array}{l}\text { Tough, } \\
\text { incompressible, } \\
\text { difficult to tear }\end{array}$ & $\begin{array}{l}\text { Soft, compressible, } \\
\text { easy to tear }\end{array}$ & $\begin{array}{l}\text { Compressible, easy } \\
\text { to tear }\end{array}$ & $\begin{array}{l}\text { Firm and barely } \\
\text { compressible }\end{array}$ \\
\hline \multirow[t]{7}{*}{5} & \multirow{7}{*}{$\begin{array}{l}\text { PF cored } \\
\text { width }(\mu \mathrm{m})\end{array}$} & 83.94 & 109.66 & 54.31 & 75.61 & 118.07 & 98.41 & \multirow[t]{7}{*}{9.17} \\
\hline & & 43.16 & 110.10 & \multirow{6}{*}{$\begin{array}{l}57.08 \\
\text { (uncored), } \\
36.23 \text { (cored) }\end{array}$} & 74.08 & \multirow[t]{6}{*}{103.74} & 95.34 & \\
\hline & & 39.33 & \multirow[t]{5}{*}{79.81} & & \multirow[t]{5}{*}{46.10} & & \multirow[t]{5}{*}{100.46} & \\
\hline & & 52.00 & & & & & & \\
\hline & & 73.03 & & & & & & \\
\hline & & 83.57 & & & & & & \\
\hline & & 91.72 & & & & & & \\
\hline \multirow[t]{7}{*}{6} & \multirow{7}{*}{$\begin{array}{l}\text { SF width } \\
(\mu \mathrm{m})\end{array}$} & 45.77 & 47.99 & 19.85 & 68.74 & \multirow[t]{7}{*}{56.84} & 63.60 & 2.27 \\
\hline & & 14.05 & 44.36 & 14.07 & 39.47 & & 55.73 & 3.27 \\
\hline & & 14.71 & 47.50 & (uncored), & 32.43 & & 45.00 & \\
\hline & & 21.90 & \multirow[t]{4}{*}{38.80} & 23.16 & & & 40.28 & \\
\hline & & 52.64 & & 14.86) & & & 34.81 & \\
\hline & & 32.56 & & & & & & \\
\hline & & 38.08 & & & & & & \\
\hline \multirow[t]{2}{*}{7} & \multirow[t]{2}{*}{ Remarks } & Dense coring & \multirow[t]{2}{*}{ Total height- $19.5 \mathrm{~cm}$} & \multirow{2}{*}{$\begin{array}{l}\text { Dry specimen, } \\
\text { highly dense } \\
\text { secondary } \\
\text { network }\end{array}$} & \multirow{2}{*}{$\begin{array}{l}\text { Total height- } 9 \mathrm{~cm} \text {, } \\
\text { basal width- } 7 \mathrm{~cm}, \\
\text { wall diameter- } 0.6 \mathrm{~cm}\end{array}$} & \multirow{2}{*}{$\begin{array}{l}\text { Densely cored } \\
\text { primary fibres }\end{array}$} & \multirow{2}{*}{$\begin{array}{l}\text { Total height- } \\
14.5 \mathrm{~cm}, \text { basal } \\
\text { width- } 13 \mathrm{~cm}\end{array}$} & \multirow{2}{*}{$\begin{array}{l}\text { Small size of fibre } \\
\text { diameters. Width } \\
\text { of polygon- } \\
35.45 \mu \mathrm{m}\end{array}$} \\
\hline & & $\begin{array}{l}\text { Wall thickness- } \\
0.2 \mathrm{~cm} \text {, wall } \\
\text { diameter- } 0.8 \mathrm{~cm}\end{array}$ & & & & & & \\
\hline
\end{tabular}

confusing and complex due to the misidentification of some of the species (Thomas, 1973; Van Soest et al., 2020). The best characters for the species delineation of the Genus Hyattella include the well-developed cored primary and uncored secondary fibers, cavernous body, unarmoured conulose surface which are useful in the taxonomic studies and easy identification of the species (Bergquist, 1980; Cook and Bergquist 2002; Cook, 2007).

In the present study the new species described are Hyattella repandus n. sp., Hyattella macrophylla n. sp., Hyattella foliata n. sp., Hyattella vedalainensis n. sp., Hyattella diffusa n. sp. and Hyattella oblongus $\mathrm{n}$. $\mathrm{sp}$. which enhances the species diversity of the genus in the Indian Ocean. Of these six species, half of them are described from the Gulf of Mannar ecosystem and one species from south west coast and one from Lakshadweep Island. It is interesting to note that Hyattella repandus $\mathrm{n}$. sp., Hyattella foliata n. sp., Hyattella diffusa n. sp. and Hyattella vedalainensis $\mathrm{n}$. $\mathrm{sp}$. have been reported from coral associated ecosystem of Gulf of Mannar whereas the Hyattella macrophylla $\mathrm{n}$. sp. from the coral reef area of Lakshadweep and Hyattella oblongus n. sp. from a rocky habitat of southwest coast of India.
Hence the present investigation is very much significant in the context of the biodiversity conservation and management of Sponge fauna of the Marine Protected Area of the Gulf of Mannar Biosphere Reserve and Lakshadweep area. It assumes significance as Phylum Porifera has been a protected group as per the schedule III of Indian Wildlife (Protection) Act, 1972 and the Aichi biodiversity targets and SDG 14 of the Convention on Biological Diversity.

\section{Acknowledgements}

Authors are thankful to Dr. A. Gopalakrishnan, Director, ICAR-CMFRI, Kochi for support and facilities provided. We are grateful to Ministry of Environment, Forests and Climate Change, New Delhi for the financial support in the form AICOPTAX project (22018.15 (1) 2015-CS (TAX) on Taxonomical Investigation on Lesser Known Marine Animals of India - Phylum Cnidaria (Class: Anthozoa) and Phylum Porifera (Marine). Special thanks to Dr. Madumitha Biswas and Dr. Rajendrakumar for providing all the logistic support from the MoEF \& CC, New Delhi. Authors are thankful to Dr. Kailash Chandra, Director and 
Dr. C. Raghunathan, Joint Director, Zoological Survey of India, Kolkata for support provided. First author is immensely thankful to Dr. Venkitaramani, Former Dean of Tuticorin Fisheries College for giving training in Principles of Taxonomy at Kochi. We are grateful to Dr. J. N. A. Hooper, Dr. Toufiek Samaai and Dr. Anita George for providing training on Marine Sponge Taxonomy at NIO, Goa. We acknowledge the sincere help provided by Dr. P. P. Manojkumar, SIC, Tuticorin, and Dr. R. Jayakumar, SIC, Mandapam during the Sponge Surveys we conducted in Gulf of Mannar.

\section{Reference}

Bergquist P. R. 1978. Sponges. London: Hutchinson and Co. 268 pp.

Bergquist, P. R. 1980. A revision of the supraspecific classification of the orders Dictyoceratidae, Dendroceratidae and Vergonida (Class Demospongiae). New Zeal. J. Zool., 7:443-503.

Bergquist, P. R and W.O. Hartman. 1969. Free amino acid patterns and the cia sification of the Demopongiae. Mar. Biol., 3(3):247- 68.

Burton, M. 1934. Sponges. Scientific Reports of the Great Barrier Reef Expedition 192829. 4 (14):513-621.

Burton, M. 1937. Supplement to the littoral fauna of Krusadai Island in the Gulf of Mannar. Bull. Madras Govt. Mus., 1(2):2-77.

Carter, H. J. 1881. Supplementary report on specimens dredged up from the Gulf of Mannar together with others from the sea in the vicinity of the Basse Rocks \& from Bass's Straits respectively, presented to the Liverpool Free Museum by Capt. W.H. Cawne Warren. Ann. Mag. Nat. Hist. Ser., 5, 7:361-385.

Cook, S. C. 2007. Clarification of dictyoceratid taxonomic characters, and the determination of genera. Porifera research, biodiversity, innovation and sustainability, p. 265-274.

Cook, S. C. and P. R. Bergquist. 2001. New species of Spongia (Porifera: Demospongiae: Dictyoceratida) from New Zealand, and a proposed sub generic structure. New Zeal. J. Mar. Fresh Wat. Res., 35:33-58.

Cook, S. C. and P. R. Bergquist. 2002. Family Spongiidae Gray, 1867. In Hooper, J. N. A \& R. W. M Van Soest (Eds) SystemaPorifera: A guide to the classification of sponges, Kluwer Academic, Plenum Publisher, New York, p. 847-863.

De Laubenfels, M. W. 1936. A discussion of the sponge fauna of the Dry Tortugas in particular and the West Indies in general, with material for revision of the families and orders of the Porifera. Carnegie Institute of Washington (Tortugas Laboratory Paper N 467), 30:1-225.

De Laubenfels, M. W. 1948. The order Keratosa of the phylum Porifera: a monographic study. Occasional Papers of the Allan Hancock Foundation, 3:1-217.

De Laubenfels, M. W. 1954. The sponges of the West -central Pacific. Oregon State Monographs. Stud. Zool., 7:1-306.

Dendy, A. 1887. XVI.-The sponge-fauna of Madras. A report on a collection of sponges obtained in the neighbourhood of Madras by Edgar Thurston, Esq. J. Nat. Hist., 20 (117):153-165.

Dendy, A. 1889. Report on a second collection of sponges from 299 the Gulf of Mannar. Ann. Mag. Nat. His. London, ser., 6, 3:73-99.

Dendy A. 1905. Report on the sponges collected by Professor Herdman, at Ceylon, in 1902. In: Herdman WA (Ed), Report to the Government of Ceylon on the Pearl Oyster Fisheries of the Gulf of Mannar. 3, Royal Society, London, p. 57-246.

Dendy, A.1916. Report on the non-Calcareous Sponges collected by Mr. James Hornell at Okhamandal in Kattiawar in 1905-6. Report to the Government of Baroda on the Marine Zoology of Okhamandal in Kattiawar, 2:93-146.

Esper, E. J. C. 1794. Die Pflanzenthiere in Abbildungen nach der Natur mit Farben erleuchtet, nebst Beschreibungen. Zweyter Theil. (Raspe: Nürnberg), p. 1-303.

Grant, R. E. 1861. Tabular view of the primary divisions of the Animal Kingdom, intended to serve as an outline of an elementary course of recent Zoology, etc., London, I-VI, $91 \mathrm{pp}$.

Gray, J. E. 1867. Notes on the arrangement of sponges, with description of some new genera. Pro. Zool. Soc. London, 1867:492-558.

Hooper, J. N. A. and R. W. M. Van Soest, 2002. Systema Porifera: a guide to the classification of sponges. Kluwer Academic /Plenum Publishers, New York, 1101 $\mathrm{pp}$.

Hyatt, A. 1877. Revision of the North American Poriferae; with Remarks upon Foreign Species. Part II. Mem. Boston Soc. Nat. Hist., 2:481-554.
Lamarck, J. B. de. (1814 [1813]). Sur les polypiers empâtés. Annales du Museum national d'Histoire naturelle. 20:294-312.

Lendenfeld, R. 1888. Descriptive catalogue of the sponges in the Australian Museum, Sidney. Taylor \& Francis, London, $260 \mathrm{pp}$.

Lendenfeld, R. 1889. A monograph of the horny sponges. Trübner and Co., London, $936 \mathrm{pp}$.

Levi, C. 1973. Systematcique de la classe de Demospongiara (Demosponges). In: P.P.Grasse (Ed.), Traite de Zoologie. Anatomie, Systematque, Biologie T.3, Spongiaires, fasc. 1:577-631.

Minchin, E. A. 1900. Chapter III. Sponges. In: Lankester, E. R. (Ed.), A Treatise on Zoology. Part II. The Porifera and Coelenterata. Adam \& Charles Black, London, p. $1-178$

Pallas, P. S. 1766. Elenchus zoophytorum sistens generum adumbrationes generaliores et specierum cognitarum succintas descriptiones, cum selectis auctorum synonymis. Fransiscum Varrentrapp, Hagae, 451 pp.

Prabhakaran, M. P., N. G. K. Pillai, P. R. Jayachandran and S. B. Nandan. 2013. Species Composition and Distribution of Sponges (Phylum: Porifera) in the Seagrass Ecosystem of Minicoy Atoll, Lakshadweep, India. In Ecology and Conservation of Tropical Marine Faunal Communities, p. 43-54.

Rao, H. S. 1941. Indian and Ceylon sponges in the naturalistoriska Riksmuseet, Stockholm, collected by K. Fistedt. Rec. Indian Mus., 43:417-496.

Sim, C. J. and K. J. Lee. 2014. Four New Species of the Genus Hyattella (Dictyoceratida: Spongiidae) from Korea. Animal. Syst. Evolution Divers., 30(1):16-21.

Sim, C. J., Y. A. Kim. and K. J. Lee. 2015. Five New Species of Genus Hyattella (Dictyoceratida: Spongiidae) from Korea. Animal Syst.Evolution Divers., 31(1):814

Sivaleela, G. 2014. Marine sponges of Gulf of mannar and Palk Bay. Reco. Zool. Surv. India, 114 (4):607-622.

Tarachand Kumawat., M. S. Varsha, A. Reshma Prasad, M. Sethulakshmi, Thobias P. Antony, M. S. Parvathy, K. B. Sheeba, Sandeep Chauhan, K. Vinod, K. R. Sreenath and K. K. Joshi. 2020. Taxonomy and biodiversity of marine sponges off Gulf of Kutch, Gujarat, India. In: Joshi K. K. et al. (Eds.). Marine Ecosystem Challenges \& Opportunities (MECOS 3), p. 275-276.

Thomas, P. A. 1973. Marine Demospongiae of Mahe Island in the Seychelles Bank (Indian Ocean). Annales du Musée royal de l'Afriquecentrale. Sciences zoologiques, (203): 1-96.

Thomas, P. A. 1979. Studies on sponges of the Mozambique channel. I. Sponges of the Inhaca Island. II. Sponges of Mambone and Paradise Islands. Annales $d u$ Musée royal de l'Afriquecentrale, Tervuren. Sciences zoologique, 227, 1-73, pls I-III.page (s), 52-53.

Thomas, P. A. 1985. Demospongiae of Minicoy Island (Indian Ocean) Part 1-Orders Keratosa and Haplosclerida. J. Mar. Biol. Ass. India, 21 (1\&2):10-16.

Thomas, P. A. 1986. Demospongiae of the Gulf of Mannar and Palk Bay. In James, P.S.B.R. (Ed.), Recent Advances in Marine Biology. New Delhi, Today Tomorrow's Printers and Publishers, p. 205-365.

Topsent, E. 1933. Eponges de Lamarck conservées au Muséum de Paris. Fin. Archives du Muséum national d'histoire naturelle, Paris. 10:1-60:38

Vacelet, J. 1959. Répartition générale des éponges et systématique des éponges cornées de la région de Marseille et de quelques stations méditerranéennes. Recueil des Travaux de la Station marine d'Endoume. 16 (26):39-101.

Van Soest, R. W. M. 1978. Marine sponges from Curacao and other Caribean localities. Part 1. Keratosa. Studies on the Fauna of Curacoa and other Caribbean Islands, 56:1-94.

Van Soest, R. W. M., N. Boury-Esnault, J. N. A. Hooper, K. Rützler, N. J. de Voogd, B. Alvarez, E. Hajidu, A. B. Pisera, R. Manconi, C. Schönberg, M. Klautau, M. Kelly, J. Vacelet, M. Dohrmann, M. C. Díaz, P. Cárdenas, J. L. Carballo, P. Ríos, R. Downey, C. C. Morrow. 2020. World Porifera Database. Accessed at http://www. marinespecies.org/porifera on 2020-06-18. doi:10.14284/359.

Varsha M. S., S. Jasmine, Molly Varghese, K. Vinod, H. Jose Kingsly, L. Ranjith, A. Reshma Prasad, M. Sethulakshmi, Thobias P. Antony, M.S, Parvathy, C. Reghunathan, K.K. Joshi and A. Gopalakrishnan. 2020a Bioinventorying of shallow water sponges (Porifera) from Kollam to Muttom. In Joshi K. K. et al. (Eds.). Marine Ecosystem Challenges \& Opportunities (MECOS 3), 241 pp.

Varsha M. S., L. Ranjith, Molly Varghese, A. Reshma Prasad, M. Sethulakshmi, Thobias P. Antony, M. S. Parvathy, N. Jesuraj, P. Muthukrishnan, I. Ravindren, A. Paulpondi, K. P. Kanthan, K. Karuppasamy, Madhumita Biswas and K. K. Joshi. 2020b. Biodiversity and distribution of sponges (Phylum: Porifera) off Tuticorin, India. In Joshi K. K. et al. (Eds.). Marine Ecosystem Challenges \& Opportunities (MECOS 3), p. $283-284$

Varsha M. S., Syed Sadik Ali, M. Sethulakshmi, A. Reshma Prasad., Thobias P. Antony, M.S. Parvathy, K. R. Aju, A. Alvin, B. Saravanakumar, R. Saravanan, Molly Varghese, K. Vinod, and K. K. Joshi. 2020 c. Sponge diversity of Thonithurai and Kilakarai areas of south-east coast of India. In Joshi K. K. et al. (Eds.). Marine Ecosystem Challenges \& Opportunities (MECOS 3), 274 pp. 